\title{
Response of Thalamocortical Neurons to Hypoxia: A Whole-Cell Patch-Clamp Study
}

\author{
Gül Erdemli and Vincenzo Crunelli \\ Physiology Unit, School of Molecular and Medical Biosciences, University of Wales Cardiff, \\ Cardiff, CF1 3US, United Kingdom
}

The effect of hypoxia (3-4 min of $95 \% \mathrm{~N}_{2}, 5 \% \mathrm{CO}_{2}$ ) on thalamocortical (TC) neurons was investigated using the wholecell patch-clamp technique in rat dorsal lateral geniculate nucleus slices kept submerged at $32^{\circ} \mathrm{C}$. The predominant feature of the response of TC neurons to hypoxia was an increase in input conductance $\left(\Delta G_{N}=117 \pm 15 \%, n=33\right)$ that was accompanied by an inward shift in baseline holding current $\left(I_{\mathrm{BH}}\right)$ at -65 and $-57 \mathrm{mV}\left(\Delta \mathrm{I}_{\mathrm{BH}}=-45 \pm 6 \mathrm{pA}, n=18\right.$, and $-25 \pm 8 \mathrm{pA}, n=33$, respectively) but not at $-40 \mathrm{mV}$. The hypoxia-induced increase in $G_{N}$ (as well as the shift in $I_{\mathrm{BH}}$ ) was abolished by procedures that are known to block $I_{\mathrm{h}}$, i.e., bath application of 4-( $N$-ethyl- $N$-phenylamino)-1,2-dimethyl-6(methylamino)-pyrimidinium chloride (100-300 $\mu \mathrm{M})\left(\Delta \mathrm{G}_{\mathrm{N}}=5 \pm\right.$ $13 \%, n=11)$ and $\mathrm{CsCl}(2-3 \mathrm{~mm})\left(\Delta G_{\mathrm{N}}=16 \pm 16 \%, n=5\right)$, or low $\left[\mathrm{Na}^{+}\right]_{\mathrm{o}}\left(\Delta \mathrm{G}_{\mathrm{N}}=10 \pm 10 \%, n=5\right)$, whereas bath application of $\mathrm{BaCl}_{2}(0.1-2.0 \mathrm{~mm})$ had no significant effect $\left(\Delta G_{N}=128 \pm\right.$ $14 \%, n=8)$. The hypoxic response was also abolished in low

A common feature of many mammalian neurons is their sensitivity to oxygen deprivation, although different types of neurons, even within the same brain region, show large variations in their sensitivity to hypoxia/ischemia (Hochachka et al., 1993; Krnjevic, 1993; Martin et al., 1997). Brief periods of hypoxia, for instance, cause a total, but apparently fully reversible, loss of synaptic transmission in the hippocampus (Leblond and Krnjevic, 1989; Krnjevic, 1993), which may be responsible for the rapid disruption of higher brain functions in the absence of oxygen. The prominent feature of the hypoxic response in hippocampal neurons is an increase in input conductance $\left(G_{\mathrm{N}}\right)$ associated with an outward shift in baseline holding current $\left(I_{\mathrm{BH}}\right)$. This effect is believed to be caused mainly by an enhanced $\mathrm{K}^{+}$conductance that may serve as a protective mechanism to decrease or delay excitotoxicity (Fujiwara et al., 1987; Krnjevic and Leblond, 1989; Leblond and Krnjevic, 1989). On the other hand, brainstem neurons, which subserve autonomic functions, are slightly depolarized in response to hypoxia, so that they maintain cardiovascular functions during oxygen deprivation (Haddad and Donelly, 1990; Cowan and Martin, 1992; Haddad and Jiang, 1993; Nolan and Waldrop, 1996).

\footnotetext{
Received Jan. 13, 1998; revised April 28, 1998; accepted May 1, 1998.

This work was supported by the Wellcome Trust (Grant 37089). We thank Bob Jones for photography and Tim Gould for technical assistance with some experiments.

Correspondence should be addressed to V. Crunelli, Physiology Unit, School of Molecular and Medical Biosciences, University of Wales Cardiff, Museum Avenue, Cardiff, CF1 3US, UK

Copyright (C) 1998 Society for Neuroscience $\quad 0270-6474 / 98 / 185212-13 \$ 05.00 / 0$
}

$\left[\mathrm{Ca}^{+2}\right]_{\mathrm{o}}\left(\Delta \mathrm{G}_{\mathrm{N}}=25 \pm 16 \%, \Delta \mathrm{B}_{\mathrm{BH}}=-6 \pm 8 \mathrm{pA}, n=13\right)$, but was unaffected by recording with electrodes containing EGTA (10 $\mathrm{mm})$, BAPTA (10-30 mm), $\mathrm{Cs}^{+}$, or $\mathrm{Cl}^{-}$, as well as in the presence of external tetraethylammonium and 4-aminopyridine. Furthermore, preincubation of the slices with botulinum toxin $A$ (100 nM), which is known to reduce $\mathrm{Ca}^{2+}$-dependent transmitter release, blocked the hypoxic response $\left(\Delta G_{N}=-3 \pm 15 \%\right.$, $\left.\Delta \mathrm{I}_{\mathrm{BH}}=10 \pm 5 \mathrm{pA}, n=4\right)$.

We suggest that a positive shift in the voltage-dependence of $I_{\mathrm{h}}$ and a change in its activation kinetics, which transforms it into a fast activating current, may be responsible for the hypoxia-induced changes in $G_{N}$ and $I_{\mathrm{BH}}$, probably via an increase in $\mathrm{Ca}^{+2}$-dependent transmitter release.

Key words: hypoxia; $\mathrm{I}_{h}$; inward rectification; cesium; ZD 7288; dorsal lateral geniculate nucleus; botulinum toxin; transmitter release

The thalamus shows a marked sensitivity to ischemic insults (Szelies et al., 1991; Steinke et al., 1992), and in situ immunohistochemical studies have revealed that both ventral and dorsal thalamic nuclei (including the ventral posterolateral, the ventral posteromedial, and the medial and dorsal lateral geniculate nucleus) are highly sensitive to ischemic challenges. Indeed, these nuclei, together with the primary sensory cortex and the basal ganglia, appear to be part of a system-preferential, topographically organized brain injury that contributes to a selective vulnerability to ischemia, particularly in the newborn (Martin et al., 1997). Although these thalamic nuclei have recently been the subject of many electrophysiological studies because of their central role in various physiological functions and in a number of neurological disorders (Jones, 1985; Steriade and Llinas, 1988; Steriade et al., 1993; Williams et al., 1996, 1997; McCormick and Bal, 1997; Turner et al., 1997), little is known about the electrical behavior of single thalamocortical (TC) neurons in response to hypoxia.

In the present experiments, we have investigated the effects of brief periods of hypoxia on TC neurons of the dorsal lateral geniculate nucleus (dLGN) maintained in slices using the wholecell patch-clamp technique. Our results suggest that activation of the hyperpolarization-activated inward current, $I_{\mathrm{h}}$, brought about by a positive shift in its voltage-dependence and changes in its kinetics, is the major factor responsible for the response of TC neurons to hypoxia.

Preliminary reports of some of these results have been published previously (Crunelli and Erdemli, 1997; Erdemli and Crunelli, 1998). 


\section{MATERIALS AND METHODS}

Slice preparation and recording solutions. For the preparation of dLGN slices, rats (Wistar, 100-150 gm) were decapitated under full anesthesia with halothane. The brain was quickly removed and placed in an ice-cold oxygenated saline (Williams et al., 1996, 1997). A block of brain tissue containing the thalamus was dissected out, and 400- $\mu$ m-thick dLGN slices were cut in a plane parallel to the optic tract using a vibroslice (Campden Instruments). Slices were then kept for at least $1 \mathrm{hr}$ at room temperature in the standard artificial CSF (ACSF) containing (in $\mathrm{mm}$ ): $\mathrm{NaCl} 134, \mathrm{KCl} 2, \mathrm{KH}_{2} \mathrm{PO}_{4} 1.25, \mathrm{Mg}_{2} \mathrm{SO}_{4} 1, \mathrm{CaCl}_{2} 2, \mathrm{NaHCO}_{3} 16$, and glucose 10 , and were aerated continuously with carbogen $\left(95 \% \mathrm{O}_{2}, 5 \%\right.$ $\mathrm{CO}_{2}, \mathrm{pH} 7.3$ ).

Before the start of the electrical recording, a slice was transferred to a submerged chamber, where both the ACSF and the aerating gas were warmed to $32 \pm 1^{\circ} \mathrm{C}$. The patch electrodes $(2.5-3 \mu \mathrm{m}$ tip diameter $)$ were prepared from $1.5 \mathrm{~mm}$ outer diameter borosilicate glass (Clark Electromedical Instruments, Pangbourne, UK) and filled with solution containing (in mM): $\mathrm{KMeSO}_{4} 118, \mathrm{KCl} 18, \mathrm{HEPES} \mathrm{10,} \mathrm{EGTA} 1$ or $10, \mathrm{CaCl}_{2} 0.1$ or $1, \mathrm{Mg}$-ATP 2, Na-GTP, 0.3 , and $\mathrm{NaCl} \mathrm{8.} \mathrm{When} \mathrm{it} \mathrm{was} \mathrm{necessary,}$ $\mathrm{KMeSO}_{4}$ was replaced by $\mathrm{KCl}$ and in some other experiments $\mathrm{KMeSO}_{4}$ and $\mathrm{KCl}$ were replaced by cesium gluconate and $\mathrm{CsCl}$, respectively. In a few experiments, CsF (118 mm) was used instead of cesium gluconate, and because the results obtained with these two internal solutions were similar, data were pooled together. In some experiments EGTA was replaced with BAPTA (10 or $30 \mathrm{~mm})$. The $\mathrm{pH}$ was always adjusted to 7.2 with $\mathrm{KOH}$ or $\mathrm{CsOH}$. The osmolarity of the internal solution (measured with a micro-osmometer, Viescor Inc.) was kept in the range of 310-320 mOsm by reducing $\left[\mathrm{KMeSO}_{4}\right]$ as needed.

To minimize the indirect effects of synaptic transmission, slices were always perfused with ACSF containing kynurenic acid (KYN, $1 \mathrm{~mm})$, picrotoxin (PIC, $100 \mu \mathrm{M})$, and tetrodotoxin $(1 \mu \mathrm{M})$ (Ben-Ari, 1990a). In some experiments PIC was replaced by $(-)$-bicuculline methiodide $(30$ $\mu \mathrm{M})$, and DL-2-amino-5-phosphonopentoic acid $(100 \mu \mathrm{M})$ (Tocris Neuramine) and 6-cyano-7-nitroquinoxaline-2,3-dione $(20 \mu \mathrm{M})$ (Tocris Neuramine) were used instead of KYN. In recordings with $\mathrm{Cs}^{+}$-filled electrodes, tetraethylammonium chloride (TEA, 10-20 mM) was also added to the perfusion medium. For low $\mathrm{Na}^{+}(16$ or $100 \mathrm{mM})$ solution, $\mathrm{Na}^{+}$was replaced either with $N$-methyl-D-glucamine $(134 \mathrm{~mm}$, tittered with $\mathrm{HCl}$ to $\mathrm{pH} 7.3)$ or TEA $(50 \mathrm{~mm})$, and $\mathrm{Ca}^{2+}$ currents were blocked by a low $\mathrm{Ca}^{2+}(0.5 \mathrm{mM})$ to high $\mathrm{Mg}^{2+}(8-10 \mathrm{~mm})$ solution containing $\mathrm{CdCl}_{2}(300$ $\mu \mathrm{M})$ and $\mathrm{NiCl}_{2}(1 \mathrm{~mm})$ (Crunelli et al., 1989; Guyon and Leresche, 1995). The following agents were also tested by bath application: 4-aminopyridine (4-AP, $0.1 \mathrm{~mm})$, botulinum toxin A (100 nM, from a stock solution in $0.2 \mathrm{M} \mathrm{NaCl}_{2}$ and $0.05 \mathrm{M}$ sodium acetate), $\mathrm{BaCl}_{2}(0.1-2$ $\mathrm{mm}), \quad \mathrm{CsCl}$ (2-3 mM), 4-( $N$-ethyl- $N$-phenylamino)-1,2-dimethyl-6(methylamino)-pyrimidinium chloride) (ZD 7288, Zeneca, UK) (100$300 \mu \mathrm{M})$. Chemicals were purchased from Sigma (Poole, UK), except where indicated.

Patch recording and data analysis. The patch electrodes had an initial resistance of 2-3 $\mathrm{M} \Omega$, and data from whole-cell recordings where the electrode series resistance increased to values $>13 \mathrm{M} \Omega$ were discarded. All recordings were done "blind," and the criteria used to identify TC neurons included the presence of a relatively large inward rectification, low-threshold $\mathrm{Ca}^{2+}$ potentials, and strong outward rectification (Williams et al., 1996). In some experiments, $0.5-1 \%$ biocytin was included in the intracellular patch electrode solution. At the end of these recording sessions, the slices were immediately fixed and then processed as described previously (Williams et al., 1996).

The electrical signals were amplified by an Axopatch 1D (Axon Instruments, Foster City, CA), and the data were analyzed with pClamp (v6.1, Axon Instruments). Cells were clamped near resting membrane potential $(-60 \mathrm{mV})$, and voltage-dependent currents were elicited by 1-sec-long hyperpolarizing and depolarizing voltage steps. Current-voltage $(I-V)$ relationships were constructed using the instantaneous current evoked by hyperpolarizing voltage steps, and the steady-state current was evoked by depolarizing voltage steps. The $G_{\mathrm{N}}$ was obtained from the slope of the first-order regression lines fitted to the linear portion of the $I-V$ plots, in the region negative to the holding potential.

The activation curve of $I_{\mathrm{h}}$ was constructed from the amplitude of the inward relaxations calculated by subtracting the instantaneous current from the steady-state current elicited by hyperpolarizing voltage steps. $I_{\mathrm{h}}$ tail currents were not used for this purpose, because the contributions of the low-threshold $\mathrm{Ca}^{2+}$ current could not be eliminated because of sensitivity of the hypoxic response to extracellular $\mathrm{Ca}^{2+}$ (see Results). For the results presented in Figure 4, the hypoxic current $I_{\text {dif }}$ (i.e., the instantaneous current recorded during hypoxia minus the instantaneous current recorded in control conditions) and $I_{\mathrm{h}}$ were normalized to their respective maximal amplitude and plotted against the step potential. The resulting data were fitted with the Boltzmann equation of the form $y=$ $1 /\left[1+\mathrm{e}^{(\mathrm{V} 1 / 2-\mathrm{Vm}) / \mathrm{k}}\right]$, where $V_{\mathrm{m}}$ is the membrane potential, $V_{1 / 2}$ is the membrane potential at which $I_{\text {dif }}$ or $I_{\mathrm{h}}$ is half-activated, and $k$ is the slope factor.

The effects of hypoxia were examined by using the method described by Leblond and Krnjevic (1989). The periods of exposure to ACSF saturated with $95 \% \mathrm{~N}_{2}, 5 \% \mathrm{CO}_{2}$ were 3-4 min long, i.e., 1-2 min longer than in the experiments by Leblond and Krnjevic (1989), in which slices were directly exposed to the aerating gases. The longer exposure used in the present study was to ensure that a major decrease in oxygen was indeed achieved in the submerged slices. Data were collected after the first 2 min of oxygen deprivation.

All quantitative data in the text and figures are expressed as mean \pm SEM, and their significance was assessed by Student's $t$ test. For unpaired differences with unequal population variances, the significance was estimated using the $d$-statistic and Fisher-Behrens distribution (Campbell, 1989).

\section{RESULTS}

The effect of hypoxia were studied in a total of 106 TC neurons. At a holding potential $\left(V_{\mathrm{H}}\right)$ of $-57.7 \pm 0.8 \mathrm{mV}$, the initial resting $G_{\mathrm{N}}$ and the $I_{\mathrm{BH}}$ of these 106 neurons were $5.8 \pm 0.4 \mathrm{nS}$ and $27 \pm$ $11 \mathrm{pA}$, respectively.

\section{Effects of hypoxia}

In the 33 neurons that were recorded with electrodes containing $\mathrm{KMeSO}_{4}$ and clamped at approximately $-57 \mathrm{mV}$, a brief period of hypoxia caused a marked and consistent increase in $G_{\mathrm{N}}\left(\Delta G_{\mathrm{N}}\right.$ $=117 \pm 15 \%)(n=33)$ and a small but significant change in $I_{\mathrm{BH}}$ $\left(\Delta I_{\mathrm{BH}}=-25 \pm 8 \mathrm{pA} ; p<0.02\right.$ from the control $I_{\mathrm{BH}}=33 \pm 16 \mathrm{pA}$; $n=33$ ) (Fig. 1A,B, Table 1). These effects were invariably accompanied by a marked increase in the instantaneous current $(101 \pm 17 \%, n=21)$, and a small increase in steady-state current (21 $\pm 6 \%, n=21$ ) evoked by hyperpolarizing voltage steps, resulting in a substantial reduction $(77 \pm 4 \%, n=21)$ of the amplitude of the inward relaxations (Fig. $1 A$ ) (control amplitude: $294 \pm 12 \mathrm{pA}, n=29$; measured at $-120 \mathrm{mV}$ ) attributable to activation of $I_{\mathrm{h}}$ (McCormick and Pape, 1990a; Soltesz et al., 1991; Pape, 1996). The inward shift in $I_{\mathrm{BH}}$ was more prominent and consistent in 18 of these neurons clamped at $-65 \mathrm{mV}\left(\Delta I_{\mathrm{BH}}=\right.$ $-45 \pm 6 \mathrm{pA} ; p<0.001$ ) (Table 1 ). On the other hand, 13 hypoxic tests performed while the neurons were held at $-40 \mathrm{mV}$ did not cause any significant change in $I_{\mathrm{BH}}\left(\Delta I_{\mathrm{BH}}=5 \pm 25 \mathrm{pA} ; n=9\right)$, although the increase in $G_{\mathrm{N}}\left(\Delta G_{\mathrm{N}}=111 \pm 23 \% ; n=9\right)$ and the decrease in the inward relaxations $(83 \pm 12 \% ; n=9)$ were still present. The reversal potential of the hypoxia-evoked current(s), obtained from the point of intersection of the instantaneous $I-V$ plots in control and during hypoxia, was $-53.7 \pm 3.2 \mathrm{mV}(n=$ 25). This value was not different from the reversal potential measured from the intersection of the regression lines fitted to the linear portion of the $I-V$ plots $(-53.2 \pm 4.7 \mathrm{mV} ; n=25)$.

The effect of hypoxia was reversible: $4-5$ min after readmission of oxygen, $G_{\mathrm{N}}, I_{\mathrm{BH}}$, and the amplitude of the inward relaxations were not significantly different from the corresponding control values $(9 \pm 17 \%, n=27 ; 13 \pm 10 \%, n=27$; and $-13 \pm 11 \%, n=$ 21 , respectively) (Figs. $1 A, B, 2,3$; see Figs. 5-8). In addition, the hypoxic challenge could be repeated at intervals of $10-15 \mathrm{~min}$ without any obvious long-lasting effect. Thus, in contrast to previous observations in other neuronal types (Reid et al., 1984; Leblond and Krnjevic, 1989), TC neurons responded to hypoxia in a very consistent and reproducible manner.

In contrast to what is usually observed in hippocampal cells (Krnjevic and Leblond, 1989; Leblond and Krnjevic, 1989), in TC 

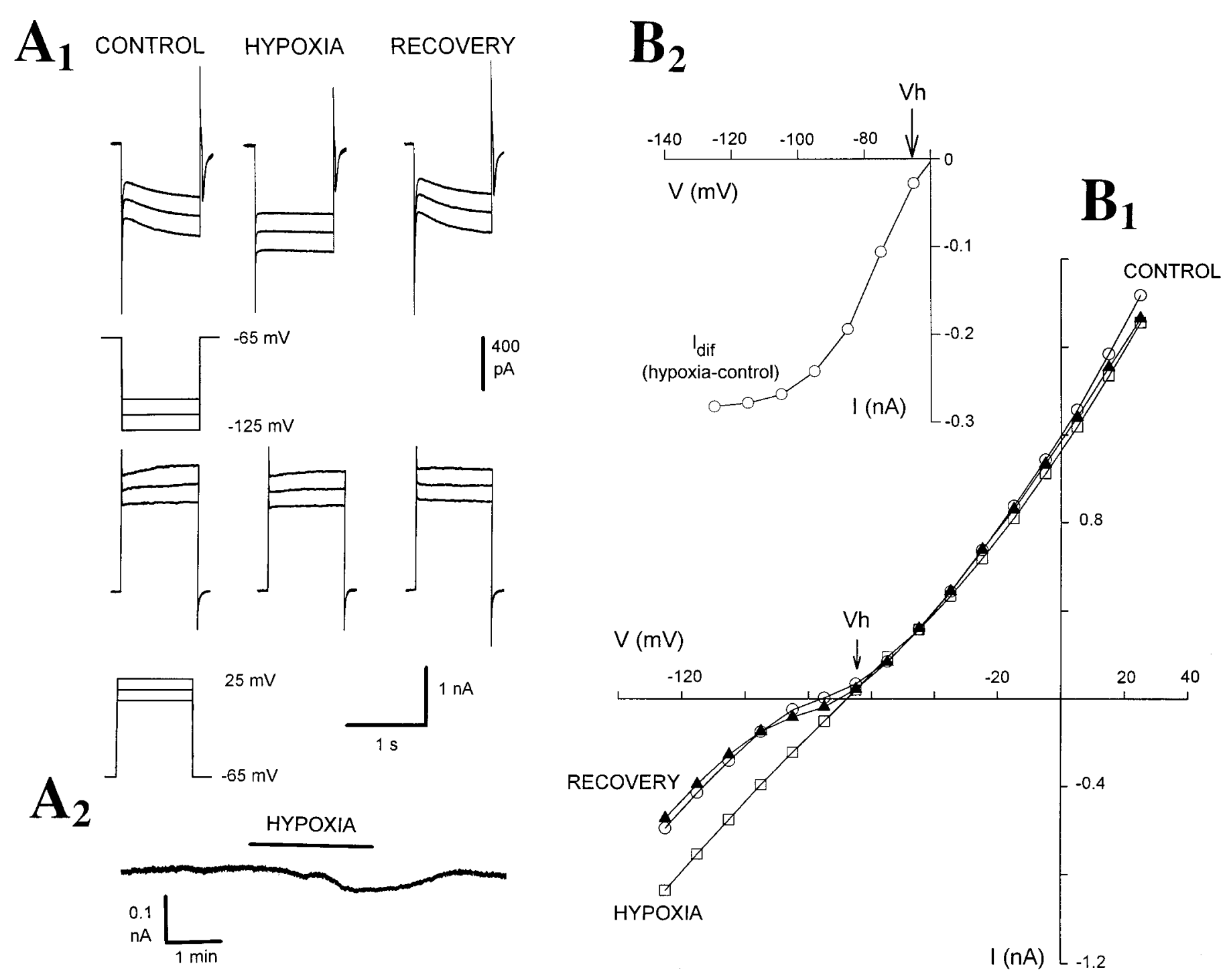

Figure 1. Hypoxia causes an increase in $G_{\mathrm{N}}$, an inward shift in $I_{\mathrm{BH}}$, and a decrease in the amplitude of inward relations in TC neurons. $A_{1}$, Voltage-clamp traces obtained with an electrode containing $\mathrm{KMeSO}_{4}$ show the inward and outward currents evoked by depolarizing and hyperpolarizing voltage steps before (CONTROL), during (HYPOXIA), and $5 \mathrm{~min}$ after hypoxia (RECOVERY). Note the marked increase in instantaneous current and the small increase in steady-state current evoked by the hyperpolarizing voltage steps during hypoxia. $A_{2}$, Continuous trace shows the inward current activated during hypoxia. $B_{1}, I-V$ plot obtained from the same neuron as in $A_{1}$ shows the substantial increase in $G_{\mathrm{N}}$ during hypoxia. In this and other $I-V$ plots in the following figures, open circles, open squares, and closed triangles represent data obtained before, during, and after hypoxia, respectively $B_{2}$, Plot of the difference current $I_{\text {dif }}$ (i.e., the instantaneous current measured during hypoxia minus the instantaneous current measured in control conditions) from the data shown in $B_{1}$. In this and the following figures, $V_{\mathrm{h}}$ indicates the holding potential (for further details, see Materials and Methods).

neurons hypoxia did not produce any significant effect on voltageactivated whole-cell outward currents $\left(I_{\text {OUT }}\right)\left(\Delta I_{\text {OUT }}=-27 \pm\right.$ $49 \mathrm{pA}$; from the control $I_{\text {OUT }}=1482 \pm 165 \mathrm{pA}$, measured at 30 $\mathrm{mV} ; n=29)$ (Fig. $\left.1 A_{1}, B_{1}\right)$.

\section{Intracellular $\mathrm{Cl}^{-}$or $\mathrm{Cs}^{+}$does not affect the hypoxia- induced changes in $\mathbf{G}_{\mathrm{N}}, I_{\mathrm{BH}}$, and inward relaxations}

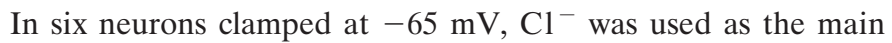
anion in the electrode solution $(\mathrm{KCl}, 136 \mathrm{mM})$, and the effect of hypoxia on $G_{\mathrm{N}}\left(\Delta G_{\mathrm{N}}=104 \pm 41 \%\right), I_{\mathrm{BH}}\left(\Delta I_{\mathrm{BH}}=-57 \pm 7 \mathrm{pA}\right)$, and the inward relaxations $(71 \pm 11 \%)$ was not different from the one observed when recording with $\mathrm{KMeSO}_{4}$-filled electrodes (Table 1). In these six cells the reversal potential of the hypoxiainduced current(s) was $-53.9 \pm 6.4 \mathrm{mV}$.
In 20 neurons recorded with electrodes containing cesium gluconate $(n=10)$ or $\mathrm{CsF}(n=10)$, hypoxia still produced a marked increase in $G_{\mathrm{N}}\left(\Delta G_{\mathrm{N}}=91 \pm 22 \% ; p<0.001\right)$, an inward shift in $I_{\mathrm{BH}}\left(\Delta I_{\mathrm{BH}}=-57 \pm 20 \mathrm{pA} ; p<0.05\right.$ from $I_{\mathrm{BH}}=95 \pm 42$ pA), and a block of the inward relaxations ( $84 \pm 10 \%)$ (Fig. $2 A, B$, Table 1). However, the reversal potential of the hypoxia-evoked current(s) recorded with $\mathrm{Cs}^{+}$-filled electrodes was shifted to a more depolarized potential $(-38.6 \pm 4.7 \mathrm{mV})$, a value similar to the reversal potential of $I_{\mathrm{h}}$ in TC neurons (McCormick and Pape, 1990a,b; Soltesz et al., 1991; Pape, 1996).

As is clearly shown in Figure $2 B$, the high-threshold $\mathrm{Ca}^{2+}$ currents of TC neurons were not depressed during a 3- to 4-minlong hypoxic challenge $\left(\Delta I_{\mathrm{Ca}}=-5 \pm 22 \%\right.$, measured at $-10 \mathrm{mV}$; 
Table 1. Effects of hypoxia on the membrane properties of thalamocortical neurons

\begin{tabular}{|c|c|c|c|c|c|}
\hline Electrode content & $n$ & $G_{\mathrm{N}}($ control $)(\mathrm{nS})$ & $G_{\mathrm{N}}($ hypoxia) $(\mathrm{nS})$ & $\Delta G_{\mathrm{N}}(\%)$ & $\Delta I_{\mathrm{BH}}(\mathrm{pA})$ \\
\hline $\mathrm{KMeSO}_{4}$ & 33 & $5.1 \pm 0.4$ & $9.5 \pm 0.9^{*}$ & $117 \pm 15^{*}$ & $-45 \pm 6^{a, *}$ \\
\hline $\mathrm{KCl}$ & 6 & $5.7 \pm 1.4$ & $8.6 \pm 2.5^{* *}$ & $104 \pm 41^{* *}$ & $-57 \pm 7^{*}$ \\
\hline Cs (fluoride or gluconate) & 20 & $4.2 \pm 0.6$ & $6.9 \pm 0.8^{*}$ & $91 \pm 22^{*}$ & $-57 \pm 20^{* *}$ \\
\hline EGTA $(10 \mathrm{~mm})$ & 11 & $3.8 \pm 0.5$ & $7.2 \pm 1.5^{* *}$ & $97 \pm 29 * *$ & $-35 \pm 17^{* * *}$ \\
\hline BAPTA $(10-30 \mathrm{~mm})$ & 13 & $8.7 \pm 0.6$ & $16.8 \pm 1.2^{*}$ & $99 \pm 16^{*}$ & $-70 \pm 20 * *$ \\
\hline
\end{tabular}

$n$, Number of cells; $G_{\mathrm{N}}$, input conductance; $I_{\mathrm{BH}}$, baseline holding current.

${ }^{a} \Delta I_{\mathrm{BH}}$ for $\mathrm{KMeSO}_{4}$-containing electrodes calculated only on 18 neurons clamped at $-65 \mathrm{mV}$.

${ }^{*} p<0.001 ; *{ }^{*} p<0.01 ; * * *<0.05$

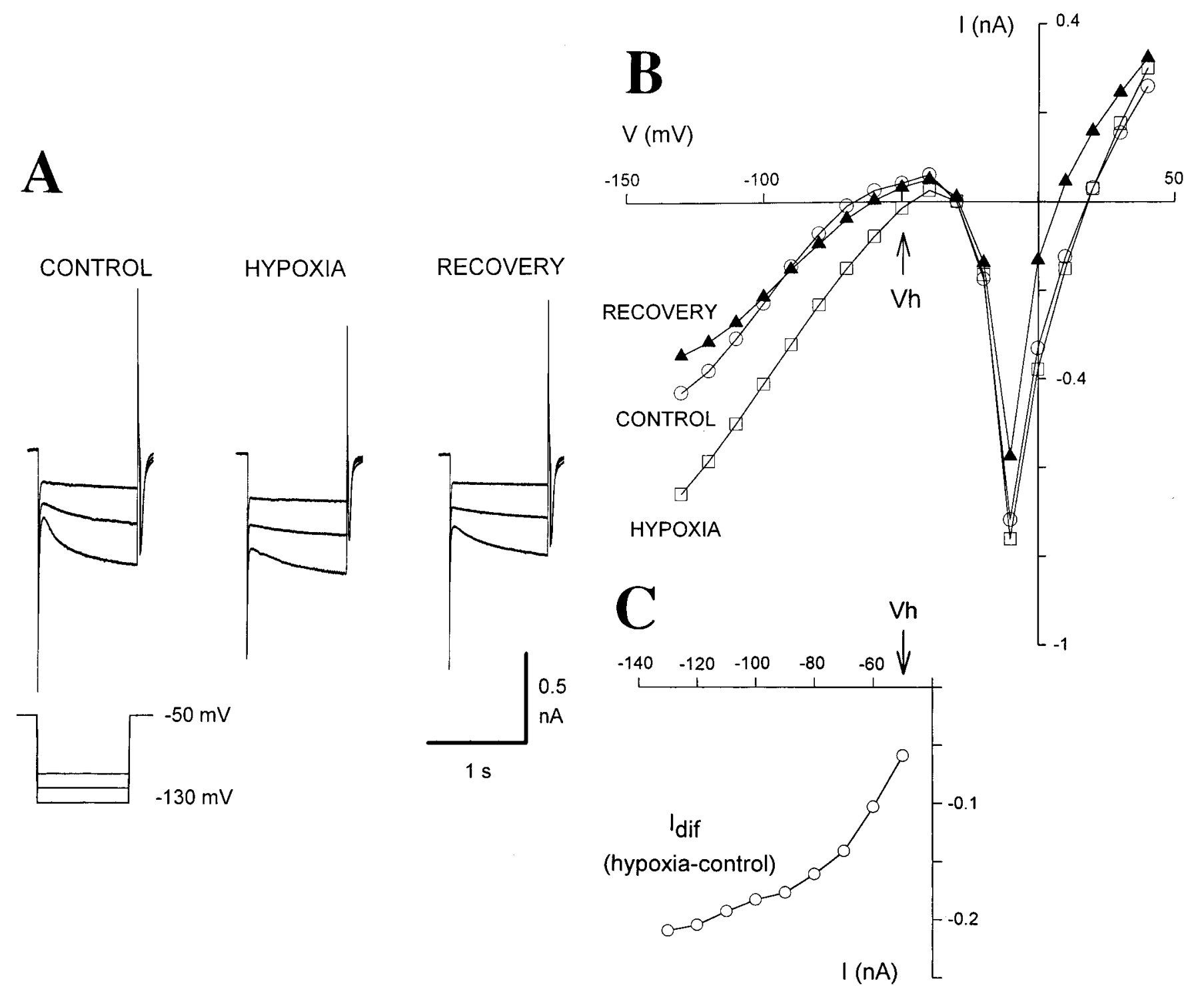

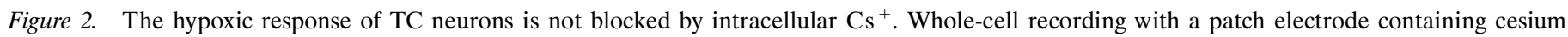

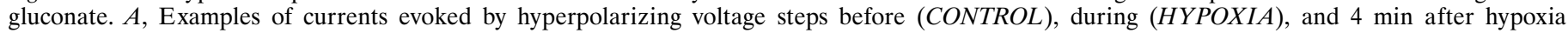

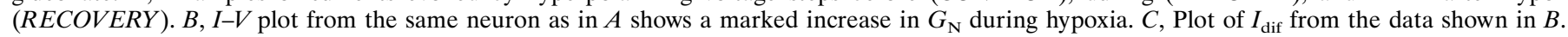

$n=13)$. This is in contrast to hippocampal neurons where high threshold $\mathrm{Ca}^{2+}$ currents are depressed in the first 3 min of oxygen deprivation after a transient initial potentiation (Krnjevic and Leblond, 1989).

\section{Effect of $\mathrm{Ba}^{2+}$}

To eliminate a possible contribution by the fast inward rectifier present in TC neurons (Williams et al., 1997), we tested the effect of $\mathrm{BaCl}_{2}$ on the hypoxic response of TC neurons. Bath applica- 

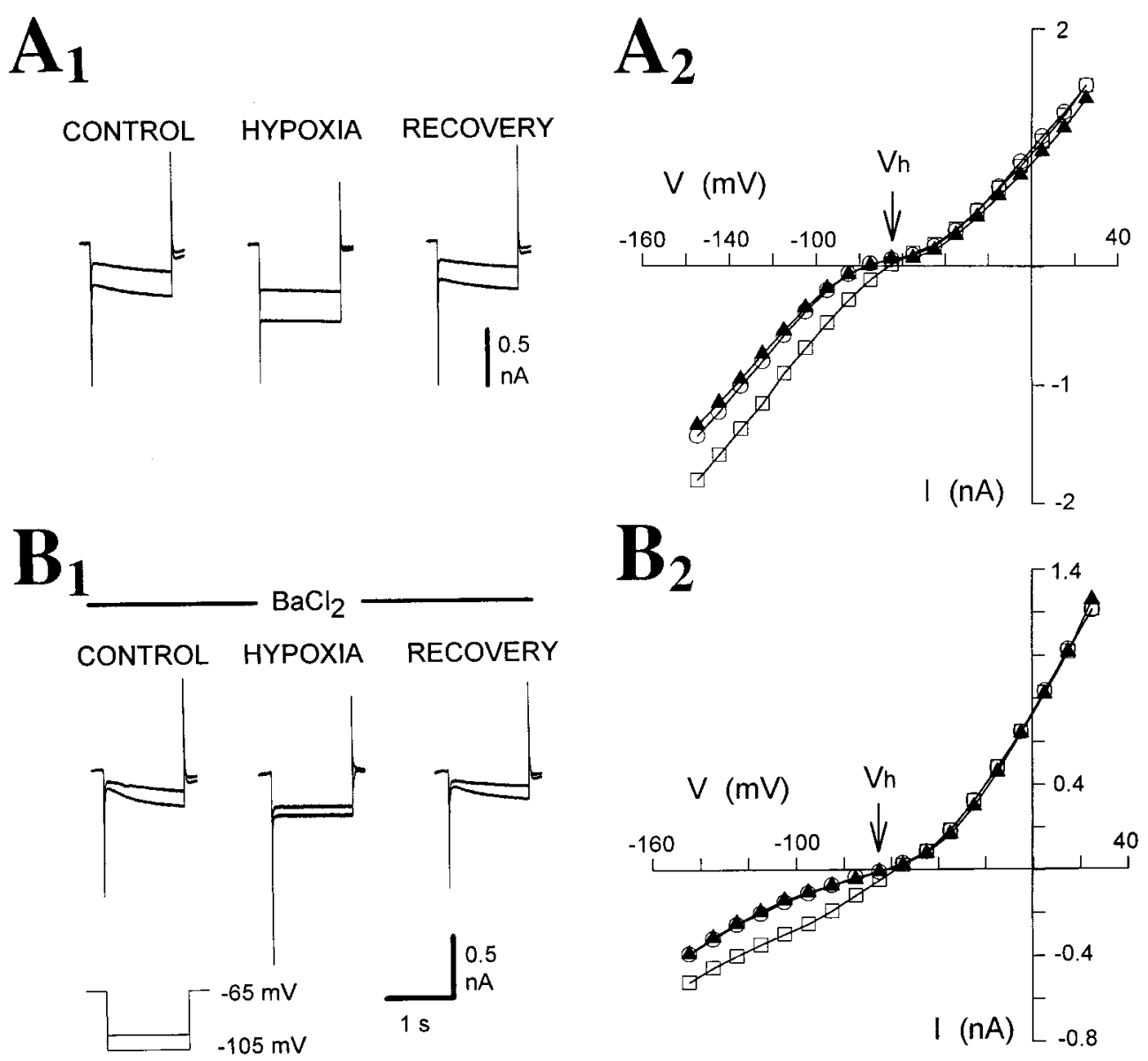

Figure 3. Bath application of $\mathrm{BaCl}_{2}$ does not affect the hypoxic response. $A_{1}, B_{1}$, Traces recorded before, during, and 4 min after hypoxia in the absence $\left(A_{1}\right)$ and presence $\left(B_{1}\right)$ of $\mathrm{BaCl}_{2}(1 \mathrm{mM})$. Note the substantial decrease in instantaneous current during perfusion with $\mathrm{BaCl}{ }_{2}$, whereas the hypoxia-induced increase in $G_{\mathrm{N}}$ and the block of inward relaxations remains in the presence of $\mathrm{BaCl}_{2} . A_{2}, B_{2}, I-V$ plots recorded before $\left(A_{2}\right)$ and during $\left(B_{2}\right) \mathrm{BaCl}_{2}$ application (data from same neuron as in $A_{1}$ and $B_{1}$, respectively).

Table 2. Pharmacological properties of the hypoxic response of thalamocortical neurons

\begin{tabular}{|c|c|c|c|c|c|}
\hline Contents of bath application & $n$ & $G_{\mathrm{N}}($ control $)(\mathrm{nS})$ & $G_{\mathrm{N}}($ hypoxia) $(\mathrm{nS})$ & $\Delta G_{\mathrm{N}}(\%)$ & $\Delta I_{\mathrm{BH}}(\mathrm{pA})$ \\
\hline ZD 7288 (0.1-0.3 mм) & 11 & $4.5 \pm 0.4$ & $5.0 \pm 0.8$ & $5 \pm 13$ & $-5 \pm 8$ \\
\hline $\mathrm{CsCl}(2-3 \mathrm{~mm})$ & 5 & $5.6 \pm 1.2$ & $6.2 \pm 2.8$ & $16 \pm 16$ & $8 \pm 7$ \\
\hline Low $\mathrm{Na}^{+}(16 \mathrm{~mm})^{a}$ & 5 & $5.7 \pm 1.04$ & $6.0 \pm 1.8$ & $10 \pm 10$ & $-14 \pm 19$ \\
\hline $\mathrm{BaCl}_{2}(0.1-2 \mathrm{~mm})$ & 8 & $3.0 \pm 0.9$ & $6.7 \pm 1.8^{*}$ & $128 \pm 14^{*}$ & $-36 \pm 9 * *$ \\
\hline Low $\mathrm{Ca}^{2+}\left(0.5 \mathrm{mM} \mathrm{Ca}^{2+}\right)^{b}$ & 13 & $3.3 \pm 0.4$ & $4.3 \pm 1.1$ & $25 \pm 16$ & $-6 \pm 8$ \\
\hline Botulinium toxin $(100 \mathrm{~nm})^{c}$ & 4 & $5.2 \pm 0.6$ & $5.0 \pm 1.3$ & $-3 \pm 15$ & $10 \pm 5$ \\
\hline
\end{tabular}

$n$, Number of cells; $G_{\mathrm{N}}$, input conductance; $I_{\mathrm{BH}}$, baseline holding current.

${ }^{a} \mathrm{Na}^{+}$was replaced with $\mathrm{N}$-methyl-D-glucamine.

${ }^{b}$ In presence of $\mathrm{Mg}^{2+}(8-10 \mathrm{~mm}), \mathrm{NiCl}_{2}(1 \mathrm{~mm})$, and $\mathrm{CdCl}_{2}(300 \mu \mathrm{M})$.

${ }^{c}$ Slices were preincubated for $2-5 \mathrm{hr}$.

$* p<0.01 ; * p<0.05$.

tion of $\mathrm{BaCl}_{2}(0.1-2 \mathrm{~mm})$ failed to produce any significant effect on the hypoxia-induced changes in $G_{\mathrm{N}}$ and $I_{\mathrm{BH}}\left(\Delta G_{\mathrm{N}}=128 \pm\right.$ $14 \%, \Delta I_{\mathrm{BH}}=-36 \pm 9 \mathrm{pA}$ in $\mathrm{BaCl}_{2}$, compared with $\Delta G_{\mathrm{N}}=$ $123 \pm 11 \%, \Delta I_{\mathrm{BH}}=-33 \pm 10 \mathrm{pA}$ in control conditions in the same eight neurons) (Fig. 3, Table 2). In two of these cells after 20 min perfusion with $\mathrm{BaCl}_{2}$ containing saline, the concomitant application of ZD $7288(100 \mu \mathrm{M})$ abolished the hypoxic response (data not shown).

\section{Voltage-dependence of the $\boldsymbol{I}_{\text {dif }}$}

In eight neurons clamped at $-40 \mathrm{mV}$ and recorded with $\mathrm{Cs}^{+}$filled electrodes in the presence of external $\mathrm{BaCl}_{2}(1-2 \mathrm{mM})$, TEA 


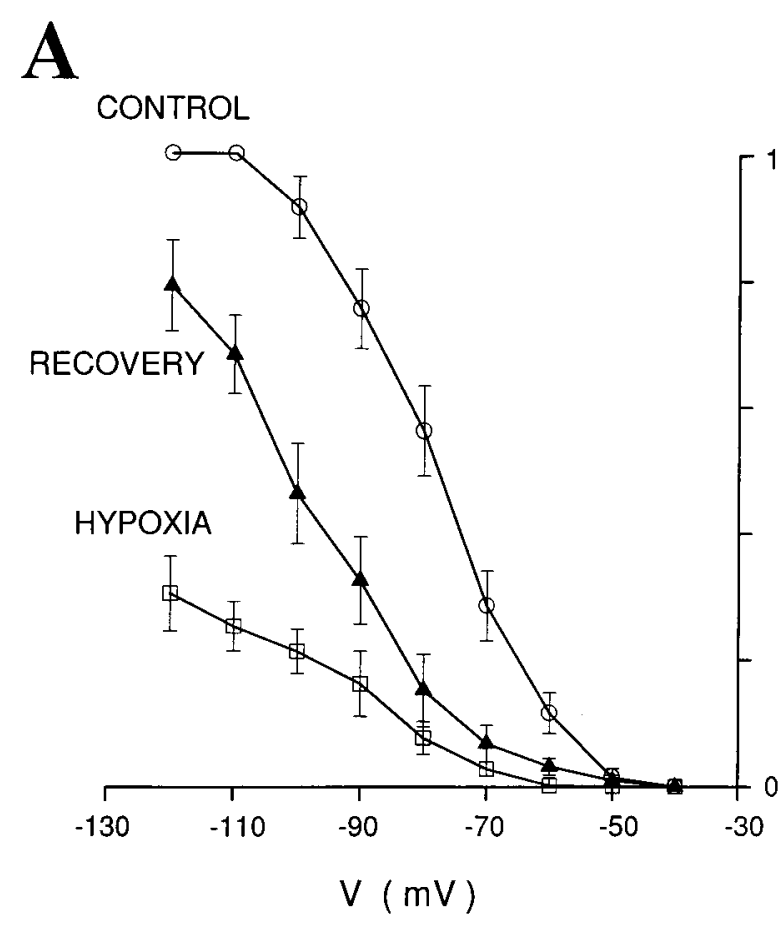

B

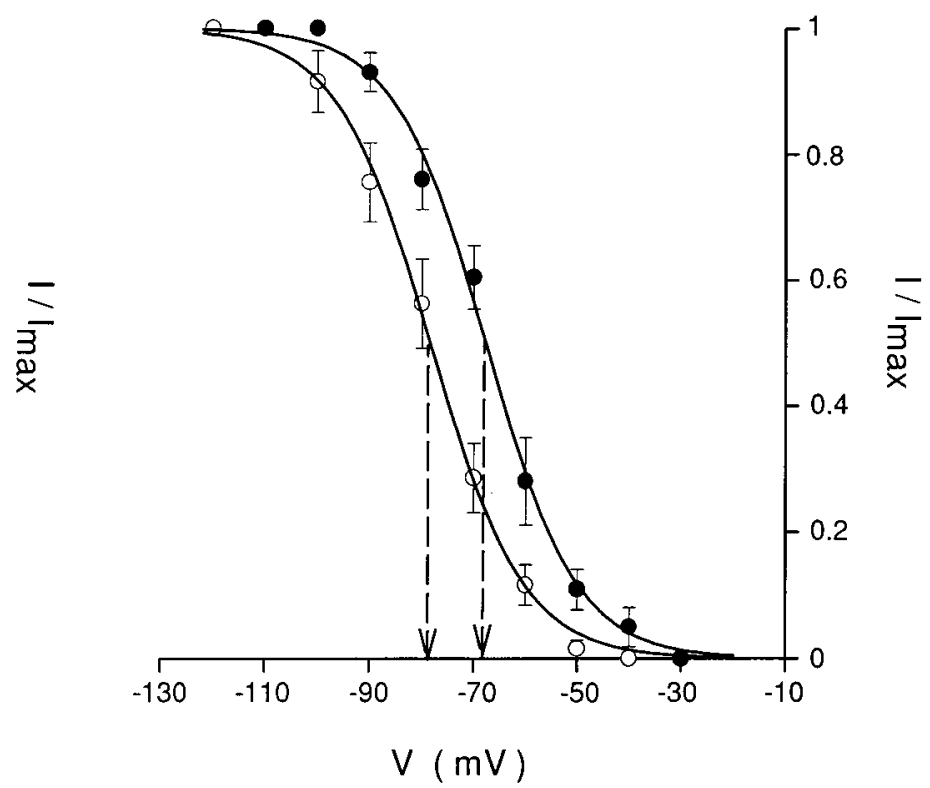

Figure 4. Effects of hypoxia on inward relaxations $\left(I_{\mathrm{h}}\right)$ and voltage-dependence of $I_{\mathrm{h}}$ and $I_{\mathrm{dif}} \cdot A$, Normalized amplitude of the inward relaxations $\left(I_{\mathrm{h}}\right)$ shows the reversible depression produced by hypoxia in eight neurons recorded with $\mathrm{Cs}^{+}$-filled electrodes in the presence of extracellular $\mathrm{BaCl}_{2}(1-2$ $\mathrm{mM})$, TEA (10-20 mM), and 4-AP (0.1 mM). Error bars represent SEM. The three data sets were normalized using $I_{\max }$ of the control data. $B$, Normalized activation curve of $I_{\mathrm{h}}$ measured in normoxic conditions $(\bigcirc)$ and normalized amplitude of $I_{\mathrm{dif}}(\bullet)$ constructed from the same eight neurons as in $A$. Error bars and curves represent SEM and the Boltzmann curves, respectively (for details, see Materials and Methods). Dashed lines point to the $V_{1 / 2}$ of the two curves. Note the similarity in slope and the $10 \mathrm{mV}$ difference in $V_{1 / 2}$ between the two curves.

(10 mM), and 4-AP (0.1 mM), we looked at the reversible effect of hypoxia on the amplitude of the inward relaxations evoked by hyperpolarizing voltage steps (Fig. $4 A$ ) and compared it with $I_{\text {dif }}$ (i.e., the difference in the instantaneous current measured in control and during hypoxia). $I_{\text {dif }}$ had a threshold for activation of approximately $-45 \mathrm{mV}$, reached a maximum at $-95 \mathrm{mV}$, and had a $V_{1 / 2}$ of $-77.6 \pm 2.3 \mathrm{mV}$ and a $k$ of $8.7 \pm 0.9(n=8)$ (Fig. $4 B$, closed circles). In agreement with previous studies (McCormick and Pape, 1990a,b; Pape, 1996; Soltesz et al., 1991), the corresponding values for $I_{\mathrm{h}}$ were $V_{1 / 2}=-88.4 \pm 2.1$ and $k=8.8 \pm 0.8$ $(n=8)$ (Fig. 4B, open circles). There was, therefore, a striking similarity between the $k$ of $I_{\text {dif }}$ and that of $I_{\mathrm{h}}$ (Fig. $4 B$ ), whereas the $V_{1 / 2}$ of $I_{\text {dif }}$ was $10 \mathrm{mV}$ more depolarized than that of $I_{\mathrm{h}}$.

\section{Block of $I_{\mathrm{h}}$ depresses the hypoxic response}

Because of the similarity in the voltage-dependence and reversal potential of $I_{\mathrm{h}}$ and $I_{\text {dif }}$, we tested the effects of ZD 7288, a selective blocker of $I_{\mathrm{h}}$ (Harris and Constanti, 1995; Williams et al., 1997) in 11 TC neurons, where in control conditions hypoxia had produced the usual increase in $G_{\mathrm{N}}\left(\Delta G_{\mathrm{N}}=109 \pm 18 \%\right)$ and inward shift in $I_{\mathrm{BH}}\left(\Delta I_{\mathrm{BH}}=-26 \pm 6 \mathrm{pA}\right)$. Bath application of ZD $7288(100-300 \mu \mathrm{M})$ blocked $I_{\mathrm{h}}$ and significantly depressed the hypoxic changes in $G_{\mathrm{N}}$ and $I_{\mathrm{BH}}$ (by $88 \pm 6$ and $92 \pm 9 \%$, respectively) (Fig. 5, Table 2). Because the action of ZD 7288 on $I_{\mathrm{h}}$ is irreversible (Harris and Constanti, 1995; Williams et al., 1997), no attempt was made to wash out the effect of ZD 7288 on the hypoxic response.

As a further test, five neurons were perfused with a solution containing 2-3 mM CsCl, a reversible blocker of $I_{\mathrm{h}}$ (McCormick and Pape, 1990a; Soltesz et al., 1991). In these conditions, $I_{\mathrm{h}}$ was blocked but hypoxia failed to produce an increase in $G_{\mathrm{N}}\left(\Delta G_{\mathrm{N}}=\right.$
$16 \pm 16 \% ; n=5)$, in contrast to the consistent $G_{\mathrm{N}}$ increase seen in the same neurons during hypoxic tests in the absence of extracellular $\operatorname{CsCl}\left(\Delta G_{\mathrm{N}}=113 \pm 19 \% ; p<0.01\right)$ (Fig. 6, Table 2 ). In two of these neurons that could be reliably clamped for a sufficient period of time, the effect of hypoxia recovered after 15 min washout of $\operatorname{CsCl}\left(\Delta G_{\mathrm{N}}=67\right.$ and $\left.82 \%\right)$ (Fig. 6).

It is well known that $I_{\mathrm{h}}$ is carried by $\mathrm{Na}^{+}$and $\mathrm{K}^{+}$ions (McCormick and Pape, 1990a; Soltesz et al., 1991). In our experiments, we reduced the $\left[\mathrm{Na}^{+}\right]_{0}$ to $16 \mathrm{~mm}$ by replacing $\mathrm{NaCl}$ with $N$-methyl-D-glucamine (134 mM). Under these conditions, $I_{\mathrm{h}}$ was blocked and the hypoxia-induced changes in $G_{\mathrm{N}}$ and $I_{\mathrm{BH}}$ were abolished $\left(\Delta G_{\mathrm{N}}=10 \pm 10 \%, \Delta I_{\mathrm{BH}}=-14 \pm 19 \mathrm{pA} ; p>0.05\right.$ for both; $n=5)$, compared with a $\Delta G_{\mathrm{N}}=99 \pm 16 \%(p<0.01)$ and a $\Delta I_{\mathrm{BH}}=-26 \pm 8 \mathrm{pA}(p<0.05)$ in control conditions. In the one neuron that could be clamped for a period sufficiently long to allow the re-establishment of the control $\left[\mathrm{Na}^{+}\right]_{\mathrm{o}}$, the hypoxic response resumed $\left(\Delta G_{\mathrm{N}}=73 \%\right)$ (data not shown).

\section{Sensitivity of the hypoxic response to $\left[\mathrm{Ca}^{2+}\right]_{\mathrm{o}}$}

Because metabolic arrest soon leads to a rise in cytosolic $\mathrm{Ca}^{2+}$ (Hansen, 1985; Kaplin et al., 1996), it has been suggested that $\mathrm{Ca}^{2+}$ could trigger the hypoxic changes in membrane properties (Krnjevic, 1993; Belousov et al., 1995).

In our experiments we tested the contribution of $\mathrm{Ca}^{2+}$. mediated changes to the hypoxic response of TC neurons by decreasing the $\left[\mathrm{Ca}^{2+}\right]_{\mathrm{o}}$ to $0.5 \mathrm{~mm}$ and increasing the $\left[\mathrm{Mg}^{2+}\right]_{\mathrm{o}}$ to 8-10 $\mathrm{mm}$ and concomitant bath application of the voltageactivated $\mathrm{Ca}^{2+}$-channel blockers $\mathrm{NiCl}_{2}(1 \mathrm{~mm})$ and $\mathrm{CdCl}_{2}(300$ $\mu \mathrm{M})$. In another five neurons the $\left[\mathrm{Mg}^{2+}\right]_{\mathrm{o}}$ was increased to $8-10$ $\mathrm{mM}$, whereas the $\left[\mathrm{Ca}^{2+}\right]_{\mathrm{o}}$ was left unchanged $(2 \mathrm{~mm})$. In all of these cells $(n=20)$, hypoxia failed to produce any significant 


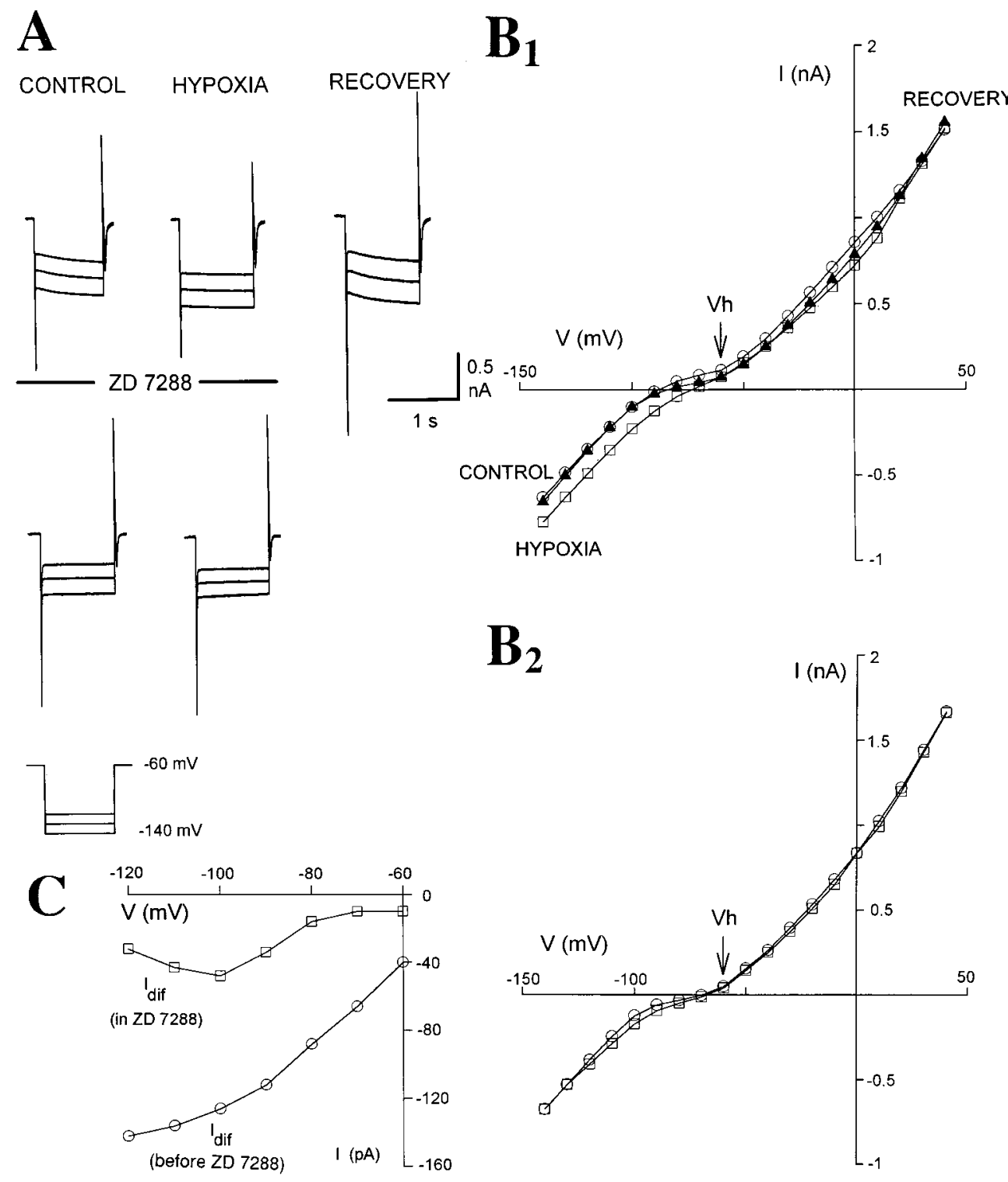

Figure 5. ZD 7288 blocks the hypoxic response of TC neurons. $A$, Examples of currents recorded in control, during, and 3 min after hypoxia in the absence (top row) and presence (bottom row) of ZD $7288(300 \mu \mathrm{M}) . B, I-V$ plots (from the same neuron as in $A$ ) obtained in the absence $\left(B_{l}\right)$ and presence $\left(B_{2}\right)$ of ZD 7288. $C, I_{\text {dif }}$ measured before $(\bigcirc)$ and during $(\square)$ bath application of ZD 7288 (from the data shown in $B_{1}$ and $B_{2}$, respectively).

changes in $G_{\mathrm{N}}$ and $I_{\mathrm{BH}}\left(\Delta G_{\mathrm{N}}=17 \pm 13 \%\right.$ and $\left.\Delta I_{\mathrm{BH}}=6 \pm 8 \mathrm{pA}\right)$ (Fig. 7, Table 2). In three of these neurons, the hypoxic response recovered 15-20 min after returning to the control solution $\left(\Delta G_{\mathrm{N}}\right.$ $=90 \pm 27 \%, \Delta I_{\mathrm{BH}}=-26 \pm 5 \mathrm{pA}$ ) (Fig. 7).

\section{Internally applied $\mathrm{Ca}^{2+}$ chelators}

An increase of the EGTA concentration (to $10 \mathrm{~mm}$ ) in the internal solution had no effect on the hypoxia-induced changes in $G_{\mathrm{N}}$ and $I_{\mathrm{BH}}$ because 21 hypoxic tests in 11 neurons produced a $97 \pm 29 \%$ increase in $G_{\mathrm{N}}$, associated with an inward shift of $-35 \pm 17 \mathrm{pA}$ in $I_{\mathrm{BH}}$ and a $89 \pm 10 \%$ reduction of the amplitude of inward relaxations (Fig. 8, Table 1). Because of the fast and pH-independent $\mathrm{Ca}^{2+}$-chelating ability, we also tested BAPTA in 13 cells. BAPTA (10 $\mathrm{mm}$ in five cells, $30 \mathrm{~mm}$ in eight cells) failed to prevent the hypoxia-induced increase in $G_{\mathrm{N}}\left(\Delta G_{\mathrm{N}}=\right.$ $99 \pm 16 \% ; n=13)$, the inward shift in $I_{\mathrm{BH}}\left(\Delta I_{\mathrm{BH}}=-70 \pm 20 \mathrm{pA}\right.$; $n=13)$, and the depression of inward relaxations $(81 \pm 14 \% ; n=$ 13) (Fig. 8, Table 1). On the other hand, neurons recorded with BAPTA, but not with $10 \mathrm{~mm}$ EGTA, showed a significantly greater $G_{\mathrm{N}}$ in control conditions compared with neurons recorded with the standard $1 \mathrm{~mm}$ EGTA in the intracellular solution (BAPTA, $G_{\mathrm{N}}=8.7 \pm 0.6 \mathrm{nS}, n=13, p<0.01$ compared with 1 mM EGTA; 10 mм EGTA, $G_{\mathrm{N}}=3.8 \pm 0.5 \mathrm{nS}, n=11$ ) (Table 1 ).

\section{Inhibition of transmitter release}

In four slices, the $\mathrm{Ca}^{2+}$-dependent release of transmitters was blocked by preincubation (2-5 hr) with botulinum toxin A (100 nM) (Sanchez-Prieto et al., 1987). In four neurons, one in each of the four slices, hypoxia failed to produce any significant effect on $G_{\mathrm{N}}\left(\Delta G_{\mathrm{N}}=-3 \pm 15 \%\right), I_{\mathrm{BH}}\left(\Delta I_{\mathrm{BH}}=-10 \pm 6 \mathrm{pA}\right)$, or the amplitude of the inward relaxations (12 $\pm 8 \%$ increase) (Fig. $9 B$, 

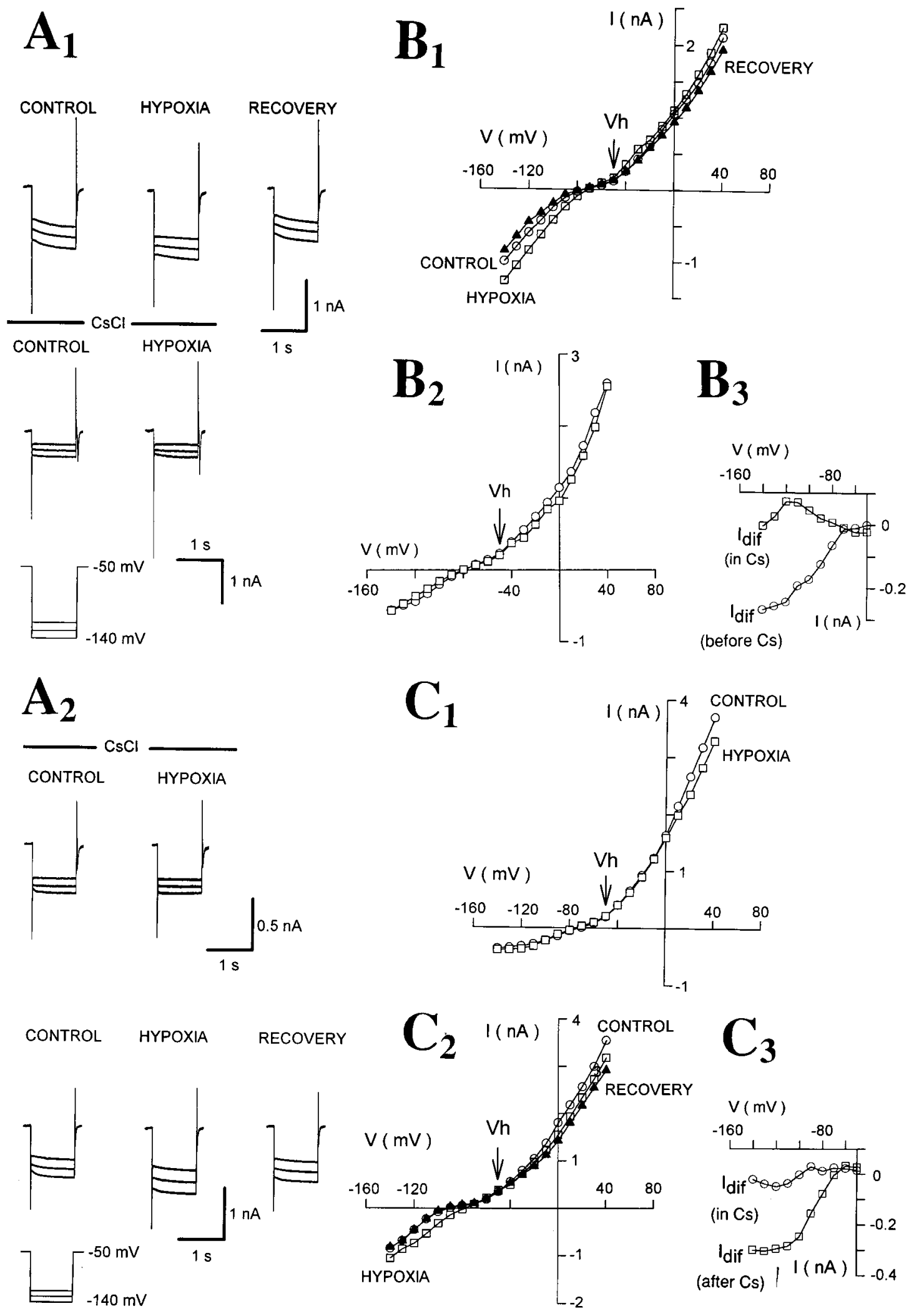

Figure 6. Bath application of $\mathrm{CsCl}$ reversibly abolishes the hypoxic response. $A_{1}$, Examples of currents evoked by hyperpolarizing voltage steps in the absence (top row) and presence (bottom row) of $\mathrm{CsCl}(3 \mathrm{mM}) . A_{2}$, Traces from another TC neuron recorded in the presence (top row) and after $15 \mathrm{~min}$ washout (bottom row) of $\mathrm{CsCl}(3 \mathrm{~mm}) . B_{1}, B_{2}, I-V$ plots measured in the absence $\left(B_{1}\right)$ and presence $\left(B_{2}\right)$ of $C \mathrm{Cl}$ from the same neuron as in $A$. $B_{3}, I_{\mathrm{dif}}$ recorded in the absence $(\bigcirc)$ and presence $(\square)$ of $\mathrm{CsCl}$ (from the data shown in $B_{1}$ and $B_{2}$, respectively). $C_{1}, C_{2}, I-V$ plots in the presence $\left(C_{1}\right)$ and after $15 \mathrm{~min}$ washout $\left(C_{2}\right)$ of $\mathrm{CsCl}(3 \mathrm{~mm})$ from the same neuron as in $A_{2} . C_{3}, I_{\text {dif }}$ measured in the presence $(\bigcirc)$ and after $15 \mathrm{~min}$ washout of $\mathrm{CsCl}(\square)$ (from the data shown in $C_{1}$ and $C_{2}$, respectively). 

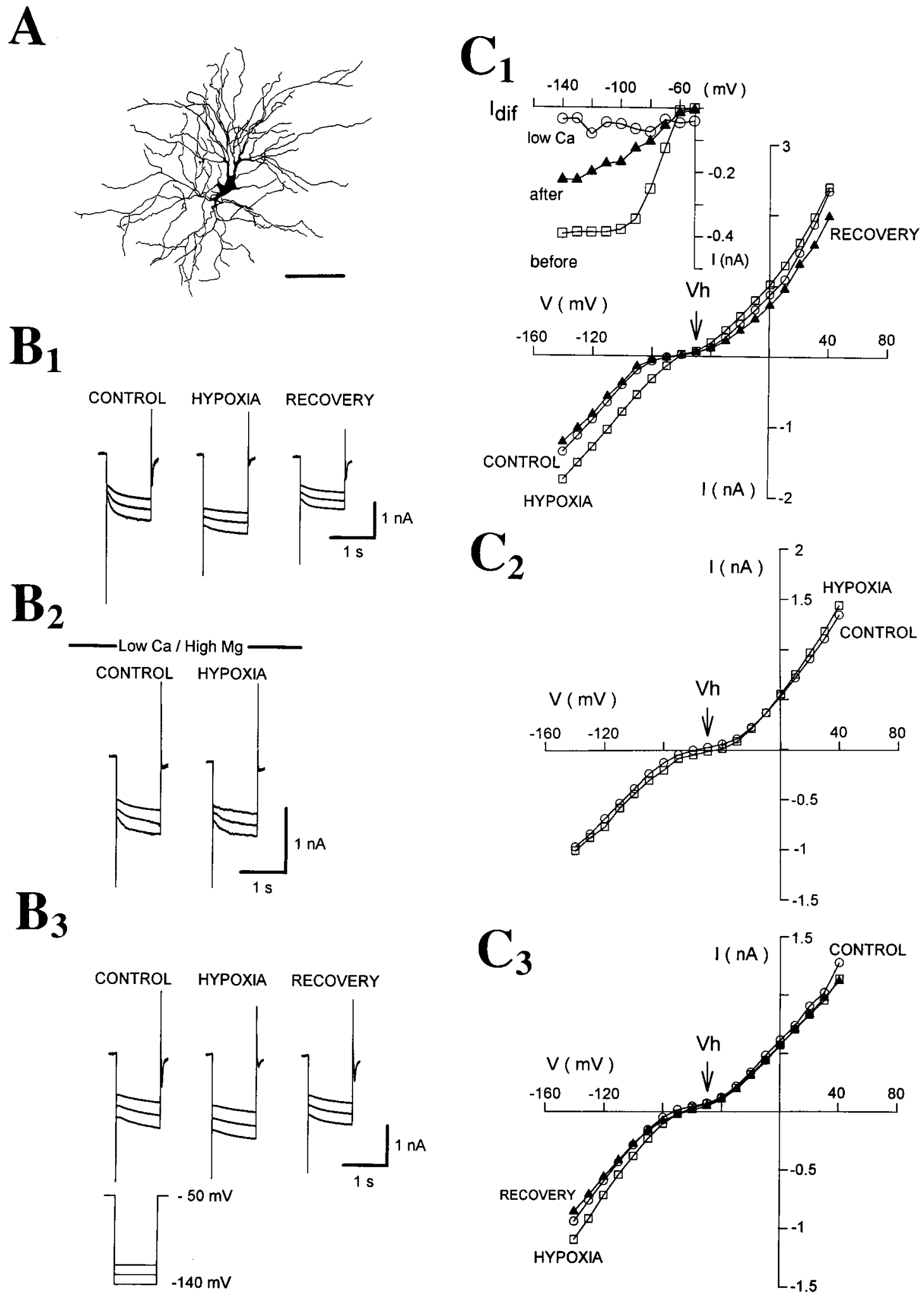

Figure 7. $\mathrm{Ca}^{2+}$ dependence of the hypoxic response. $A$, Camera lucida reconstruction of the neuron (from which all data in this figure were obtained) shows the characteristic morphology of a dLGN TC neuron. Whole-cell recording with a biocitin-containing patch electrode obtained in standard ACSF $\left(B_{1}, C_{1}\right)$, then in solution containing low $\mathrm{Ca}^{2+}(0.5 \mathrm{mM})$, high $\mathrm{Mg}^{2+}(8 \mathrm{mM}), \mathrm{NiCl}_{2}(1 \mathrm{mM})$, and $\mathrm{CdCl}_{2}(300 \mu \mathrm{M})\left(B_{2}, C_{2}\right)$, and during washout with standard $\operatorname{ACSF}\left(B_{3}, C_{3}\right)$. In all cases, examples of currents recorded before, during, and 4 min after hypoxia are shown. $C_{1}, C_{2}, C_{3}, I-V$ plots obtained

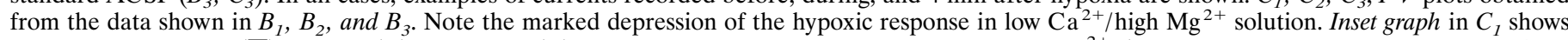
$I_{\text {dif }}$ measured before $(\square)$, during $(O)$, and after $(\mathbf{\Delta})$ perfusion with the solution containing low $\mathrm{Ca}^{2+}$ (from the data shown in $C_{1}$, $C_{2}$, and $C_{3}$, respectively). 

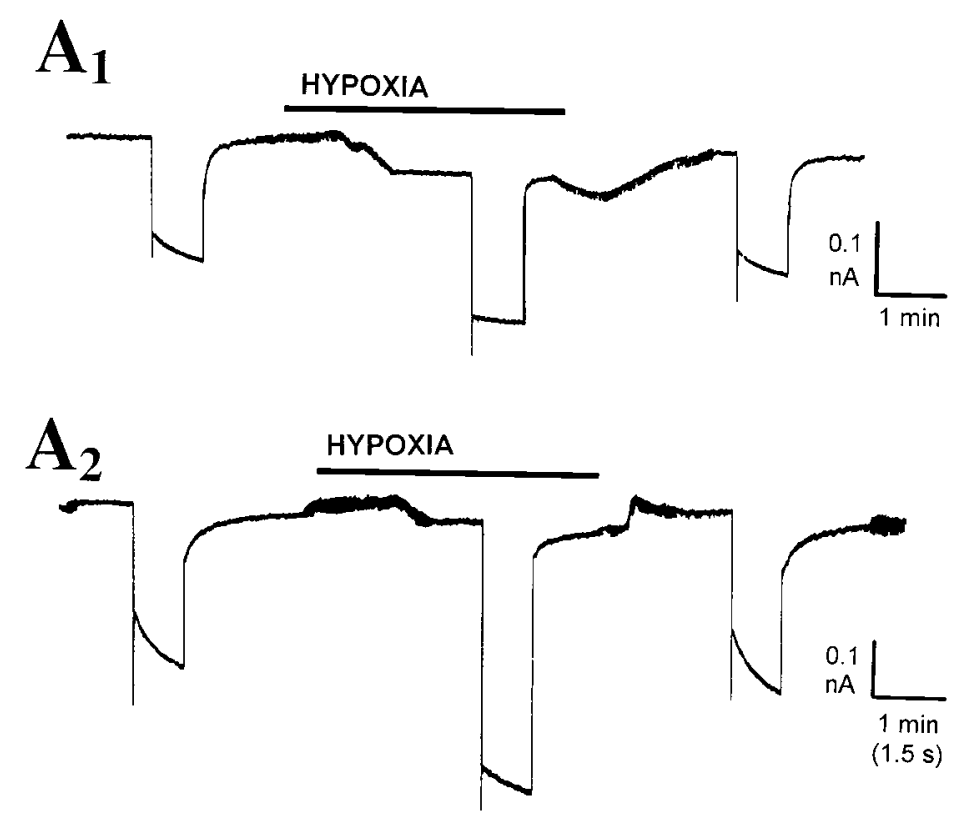

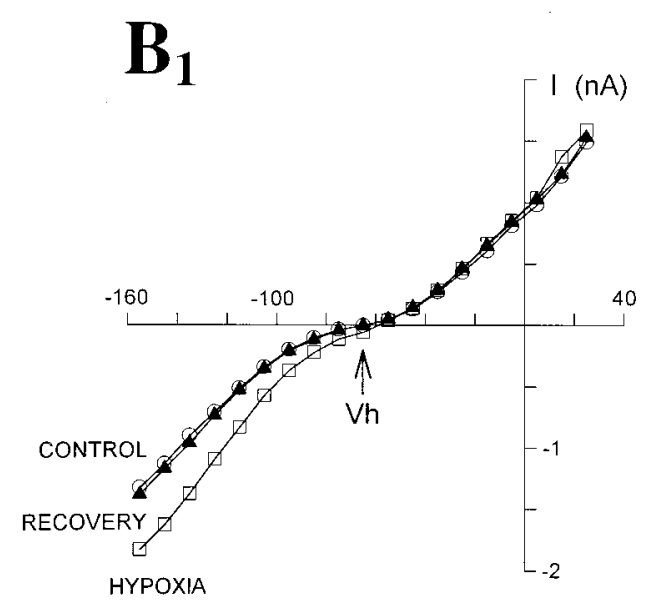

Table 2). Note that preincubation of the slices had no effect on the amplitude of the inward relaxations $(332 \pm 53 \mathrm{pA} ; n=4)$ (Fig. 9).

\section{Block of transmitter receptors}

Because the sensitivity to botulinum toxin of the hypoxic response of TC neurons suggested an involvement of presynaptic mechanisms, we further assessed this hypothesis by testing the effect of antagonists for transmitter receptors whose activation is known to affect $I_{\mathrm{h}}$ in TC neurons. Combined application of propanol $(30 \mu \mathrm{M})$, cimetidine $(50 \mu \mathrm{M})$, and methysergide $(30 \mu \mathrm{M})$ produced a significant reduction in the effect of hypoxia on $G_{\mathrm{N}}$ $(58 \pm 17 \%), I_{\mathrm{BH}}(48 \pm 2 \%)$, and $I_{\mathrm{h}}(45 \pm 9 \%)$ in three TC neurons (each in a different slice).

\section{DISCUSSION}

The main findings of this study in TC neurons of the rat dLGN are that (1) brief periods of hypoxia cause an inward shift in $I_{\mathrm{BH}}$, accompanied by an increase in $G_{\mathrm{N}}$ and a decrease in the amplitude of the inward relaxations elicited by hyperpolarizing voltage steps, and (2) these hypoxia-induced changes are $\mathrm{Ca}^{2+}$ dependent and abolished by selective blockers of $I_{\mathrm{h}}$ and by botulinum toxin but are unaffected by high concentrations of internally applied $\mathrm{Ca}^{2+}$ chelators. The simplest explanation of these results is that hypoxia causes a $10 \mathrm{mV}$ positive shift in the voltage-dependence of $I_{\mathrm{h}}$ together with a change in its kinetics that transforms $I_{\mathrm{h}}$ into a fast activating current. An increase in $\mathrm{Ca}^{2+}$-dependent release of transmitters may underlie some of these effects.

\section{Mechanism of the hypoxia-induced changes in $\mathbf{G}_{\mathbf{N}}$ and $I_{\mathrm{BH}}$ $\mathrm{K}^{+}$and $\mathrm{Cl}^{-}$channels}

An increase in $G_{\mathrm{N}}$ caused by the activation of $\mathrm{K}^{+}$currents during hypoxia by either a depletion of intracellular ATP (Ben-Ari, 1990b; Fujimura et al., 1997) or an increase in $\left[\mathrm{Ca}^{2+}\right]_{\mathrm{i}}$ (Belousov et al., 1995) has been shown in hippocampal slices. In our experiments, however, no significant change in either voltage-activated outward currents (in the range from -40 to $30 \mathrm{mV}$ ) or $I_{\mathrm{BH}}$ (at potentials more than or equal to $-40 \mathrm{mV}$ ) was observed during 


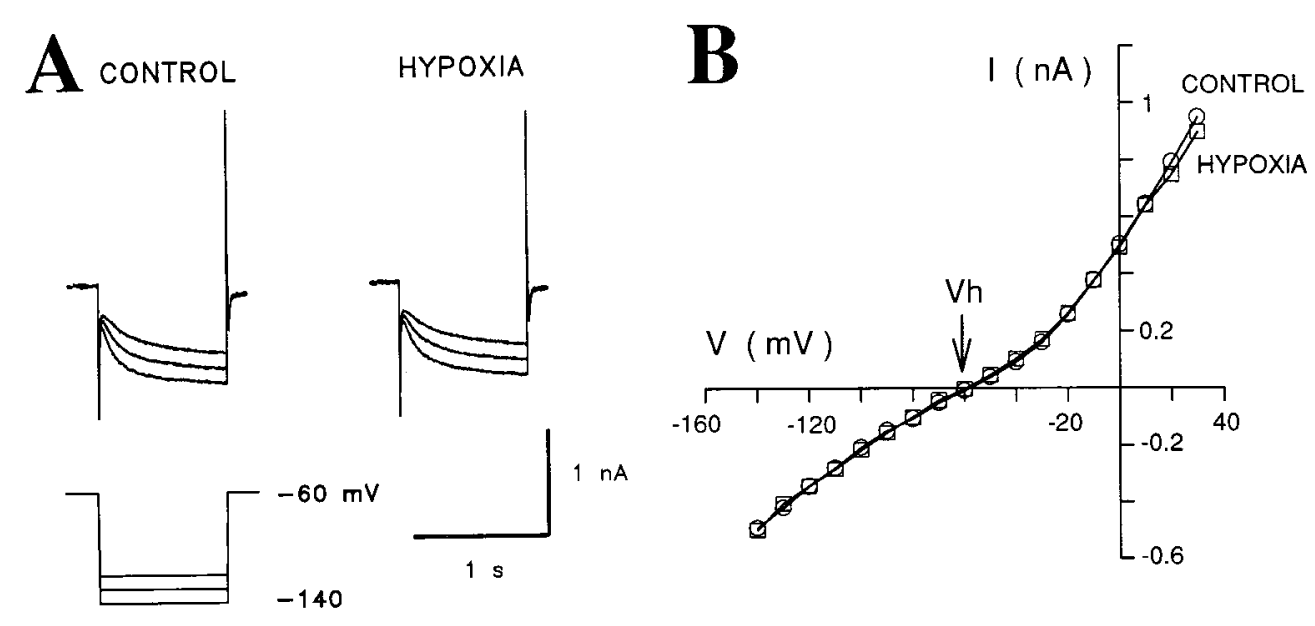

Figure 9. Lack of hypoxic response in $\mathrm{TC}$ neurons preincubated with botulinum toxin $\mathrm{A}$. $A$, Whole-cell recording with an electrode containing $\mathrm{KMeSO}_{4}$ shows the absence of any effect of hypoxia in a TC neuron from a slice preincubated with botulinum toxin A ( $100 \mathrm{nM})$ for $4 \mathrm{hr}$. $B, I-V$ plot from the same neuron as in $A$.

hypoxia. In addition, internally applied $\mathrm{Cs}^{+}$, which has been widely used as a powerful tool for eliminating various $\mathrm{K}^{+}$currents (Gay and Stanfield, 1977; Cook, 1988; Halliwell, 1990), together with bath applications of TEA, $\mathrm{BaCl}_{2}$, and 4-AP, failed to affect the hypoxia-induced changes in $G_{\mathrm{N}}, I_{\mathrm{BH}}$, and inward relaxations. The lack of effect of $\mathrm{BaCl}_{2}$ also indicates that the hypoxia-induced depression of the inward relaxations was not secondary to a $\mathrm{K}^{+}$current activation as shown in substantia nigra, zona compacta neurons (Watts et al., 1996) and eliminates a possible contribution of a leak conductance (Hagiwara et al., 1978; Cook, 1988; Halliwell, 1990) and the fast inward rectifier (Williams et al., 1997) to the hypoxic response of TC neurons.

The reversal potential of the hypoxia-induced current, however, was shifted from -57 to $-37 \mathrm{mV}$ when recording with $\mathrm{Cs}^{+}$-filled electrodes, suggesting some contribution by current(s) with a reversal potential less than $-57 \mathrm{mV}$. In contrast to previous results in the hippocampus (Zhang and Krnjevic, 1993; Belousov et al., 1995), the lack of any difference in the effect of hypoxia measured with either $\mathrm{MeSO}^{-}{ }_{4}^{-}, \mathrm{Cl}^{-}-, \mathrm{F}^{-}$, , or gluconate-filled electrodes excluded any significant contribution of $\mathrm{Cl}^{-}$currents to the hypoxic response. Together these results indicates that current or currents with a reversal potential less than $-57 \mathrm{mV}$, possibly carried by $\mathrm{K}^{+}$and blocked by internal $\mathrm{Cs}^{+}$, contribute to the hypoxic response of TC neurons. No further attempt was made in this study to identify this current(s).

\section{$\mathrm{I}_{h}$ channels}

A consistent block of the hypoxic response was observed with three different manipulations that are known to abolish $I_{\mathrm{h}}$ in TC neurons: bath applications of ZD 7288 (Williams et al., 1997) and of CsCl (McCormick and Pape, 1990a; Soltesz et al., 1991) and a decrease in $\left[\mathrm{Na}^{+}\right]_{\mathrm{o}}$ (McCormick and Pape, 1990a). The reversibility of the block produced by the last two procedures suggests that this abolishment of the hypoxic response is attributable to a selective block of $I_{\mathrm{h}}$ and not to a rundown of the hypoxic response, as has been observed in the hippocampus (Z hang and Krnjevic, 1993). Although extracellular $\mathrm{Cs}^{+}$has been shown to depress the M-current (Coggan et al., 1994), which may also have been enhanced by a hypoxia-induced rise in $\left[\mathrm{Ca}^{2+}\right]_{\mathrm{i}}(\mathrm{Yu}$ et al., 1994), there is no study that indicates a similar effect of ZD 7288 and low $\left[\mathrm{Na}^{+}\right]_{\mathrm{o}}$ on this voltage-activated $\mathrm{K}^{+}$current.

Thus, the pharmacological sensitivity and the reversal potential (measured with $\mathrm{Cs}^{+}$-filled electrodes) of $I_{\text {dif }}$ are identical to those of $I_{\mathrm{h}}$, suggesting that the former current may represent $I_{\mathrm{h}}$ that has undergone a $10 \mathrm{mV}$ positive shift in its voltage-dependence caused by hypoxia. This interpretation accounts for the hypoxiainduced inward change in $I_{\mathrm{BH}}$ (observed at more depolarized potentials than the normal activation range of $I_{\mathrm{h}}$ ) and for the increase in steady-state current. During hypoxia, therefore, $I_{\mathrm{h}}$ might be activated and not blocked, as the depression of the inward relaxations might indicate. In line with this suggestion, our explanation for the substantial increase in instantaneous current and the resulting depression of the inward relaxations is that hypoxia somehow changes the kinetics of $I_{\mathrm{h}}$, transforming it into a fast activating current. Under these conditions, $I_{\mathrm{h}}$ channels would open within a few milliseconds of the start of hyperpolarizing voltage steps, explaining the large increase in instantaneous current (as well as in $G_{\mathrm{N}}$ ) and the depression of inward relaxations. Clearly, this scenario represents the most parsimonious explanation of the present results, but we cannot exclude the alternative possibility that in TC neurons hypoxia blocks $I_{\mathrm{h}}$ and concomitantly activates a novel, very fast activating current that has a voltage-dependence similar to, and pharmacological properties and an ionic permeability identical to, those of $I_{\mathrm{h}}$.

\section{What activates $I_{\mathrm{h}}$ during hypoxia?}

$\mathrm{Ca}^{2+}$-dependence of the hypoxic response

The hypoxic response of TC neurons was found to be highly sensitive to $\left[\mathrm{Ca}^{2+}\right]_{0}$, although there is no direct evidence from TC neurons, measurements of $\mathrm{Ca}^{2+}$ influx or $\left[\mathrm{Ca}^{2+}\right]_{\mathrm{i}}$ in other brain regions have shown that hypoxia can elicit an increase in cytosolic $\mathrm{Ca}^{2+}$ (Hansen, 1985; Kass and Lipton, 1986; Dubinsky and Rothman, 1991; Kaplin et al., 1996). This increased $\left[\mathrm{Ca}^{2+}\right]_{\mathrm{i}}$ may play a role both presynaptically by increasing transmitter release and postsynaptically by directly activating $I_{\mathrm{h}}$ (Hagiwara and Irisawa, 1989; Ingram and Williams, 1996) or the other current(s) responsible for the hypoxia-mediated effects in TC neurons.

In our experiments, we did not observe any significant effect of hypoxia on high voltage-activated $\mathrm{Ca}^{2+}$ currents. In addition, the lack of action of high concentrations of internally applied $\mathrm{Ca}^{2+}$ chelators does not support a postsynaptic origin of the $\mathrm{Ca}^{2+}$. dependence of the hypoxic response, although the effectiveness of these chelators would be somewhat limited if the hypoxiaactivated channels were locally regulated by $\mathrm{Ca}^{2+}$ released from 
internal stores close to the surface membrane or if $\mathrm{Ca}^{2+}$ would enter the neuron via channels located in close proximity to the hypoxia-activated channels. The increase in resting $G_{\mathrm{N}}$ observed when using BAPTA (cf. Zhang et al., 1995) may indicate that a $\mathrm{K}^{+}$conductance, which is normally suppressed by the normal $\left[\mathrm{Ca}^{2+}\right]_{\mathrm{i}}$, is activated when BAPTA lowers $\left[\mathrm{Ca}^{2+}\right]_{\mathrm{i}}$ below a critical level, as is the case for $r$-eag type of $g_{K}$ (Stansfeld et al., 1996).

The lack of action of internally applied $\mathrm{Ca}^{2+}$ chelators and the block by botulinum toxin, an agent known to inhibit $\mathrm{Ca}^{2+}$ dependent transmitter release (Sanchez-Prieto et al., 1987), suggest that the $\mathrm{Ca}^{2+}$-dependence of the hypoxic response of TC neurons is likely to have a presynaptic origin, i.e., during hypoxia the $\mathrm{Ca}^{2+}$-dependent release of transmitters may increase, therefore leading indirectly to some of the observed effects of hypoxia. In ischemic conditions, (i.e., lack of oxygen and glucose) $\mathrm{Ca}^{2+}$ independent release of transmitters is increased because of reverse operation of the uptake system, secondary to a reduced $\mathrm{Na}^{+}$electrochemical gradient (Kauppinen et al., 1988; Nicholls and Attwell, 1990; Szatkowski and Attwell, 1994). Depletion of the $[\text { ATP }]_{i}$, which is essential for the $\mathrm{Na}^{+} / \mathrm{K}^{+}$exchanger, is the major factor responsible for a reduced $\mathrm{Na}^{+}$electrochemical gradient. On the other hand, oxygen deprivation alone, i.e., not accompanied by hypoglycemia, causes only very minor changes in $[\mathrm{ATP}]_{\mathrm{i}}$ (Madl and Burgesser, 1993), indicating that the $\mathrm{Ca}^{2+}$ dependent transmitter release may be upregulated during brief periods of hypoxia.

\section{Might transmitters activate $\mathrm{I}_{h}$ during hypoxia?}

The results of the above experiments indicate that an increase in transmitter release might underlie some of the effects of hypoxia in TC neurons. Interestingly, several neurotransmitters, including noradrenaline, serotonin (McCormick and Pape, 1990b; Soltesz et al., 1991), histamine (McCormick and Williamson, 1991), and nitric oxide (Pape and Mager, 1992; for review, see Pape, 1996) are known to increase $I_{\mathrm{h}}$ in TC neurons by eliciting a positive shift in its steady-state activation curve. This action gives rise to an inward current at potentials around $-60 \mathrm{mV}$ and an increase in steady-state current elicited by hyperpolarizing voltage steps (McCormick and Pape, 1990b; Soltesz et al., 1991; Pape, 1996). The size of this inward current and the magnitude of this increase in steady-state current are comparable to the shift in $I_{\mathrm{BH}}$ and to the increase in steady-state current, respectively, evoked during hypoxia. It is reasonable, therefore, to suggest that a hypoxiamediated release of one or more of these transmitters may be responsible for some of the effects elicited by hypoxia in TC neurons. Indeed, strong support for this hypothesis is provided by the finding that a combined block of noradrenaline $(\beta)$, serotonin, and histamine $\left(\mathrm{H}_{2}\right)$ receptors produced a substantial reduction of the hypoxic response.

Although an increase in the activation rate of $I_{\mathrm{h}}$ in the presence of these transmitters has been reported (McCormick and Pape, 1990a,b; McCormick and Williamson, 1991), none of them, applied alone, has been shown to be able to produce as large a change in the kinetics properties of $I_{\mathrm{h}}$ as to transform it into a very fast activating (i.e., instantaneous) current during hypoxia. Interestingly, each of these transmitters increases the instantaneous current slightly (compare Fig. 5, $A$ and $C$, in McCormick and Pape, 1990b; and Fig. 6, $A$ and $B$, in McCormick and Williamson, 1991), and forskolin, which mimics the effects of noradrenaline and serotonin on $I_{\mathrm{h}}$ in TC neurons (Pape, 1996), appears to be able to transform $I_{\mathrm{Q}}$ of sympathetic neurons into an instantaneous current (D. A. Brown, personal communication).
Nevertheless, several possibilities for the large, hypoxia-mediated change in $I_{\mathrm{h}}$ kinetics remain to be elucidated: (1) a synergistic action of known thalamic transmitters, possibly involving both cAMP and cGMP; (2) the action of some unknown transmitter(s) released during hypoxia; and (3) the additional action of hypoxiamediated postsynaptic effects, such as changes in intracellular $\mathrm{pH}$ or cell swelling.

\section{Pathophysiological role of $I_{\mathrm{h}}$ activation during hypoxia}

It has been shown that hypoxia/ischemia causes highly organized, system-preferential, topographic encephalopathy and targets regions that play a pivotal role in sensory integration. Injury mediated by oxygen deprivation is found preferentially in the somatosensory cortex, the basal ganglia (including putamen and subthalamic nucleus), the ventral thalamus, the medial and dorsal LGN, and the tectal nuclei (Martin et al., 1997). The hypoxiamediated inward current and increase in conductance observed in this study will affect the amplitude and kinetics of synaptic potentials generated in, and as a consequence the output of, TC neurons. These effects may be carried forward from the thalamus to the cortex via corticothalamic connections (Jones, 1985; Salt et al., 1995;) and then to the striatum and the subthalamus via corticosubthalamic projections (Fujimoto and Kita, 1993; Bevan et al., 1995; Jones et al., 1977), explaining the topographic cascade of transneuronal injury in brain areas involved in sensorimotor integration.

\section{REFERENCES}

Belousov AB, Godfraind J-M, Krnjevic K (1995) Internal $\mathrm{Ca}^{2+}$ stores involved in anoxic responses of rat hippocampal neurones. J Physiol (Lond) 486:547-556.

Ben-Ari Y (1990a) Galanine and glibenclamide modulate the anoxic release of glutamate in rat CA3 hippocampal neurons. Eur J Neurosci 2:62-68.

Ben-Ari Y (1990b) Hippocampal potassium ATP channels and anoxia: presynaptic, postsynaptic or both. Trend Neurosci 13:409-410.

Bevan MD, Francis CM, Bolam JP (1995) The glutamate-enriched cortical and thalamic input to neurons in the subthalamic nucleus of the rat: convergence with GABA-positive terminals. J Comp Neurol 361:491-511.

Campbell RC (1989) Statistics for biologists. Cambridge, UK: Cambridge UP.

Coggan JS, Purnyn SL, Knoper SR, Kreulen DL (1994) Muscarinic inhibition of two potassium currents in guinea-pig prevertebral neurons: differentiation by extracellular cesium. Neuroscience 59:349-361.

Cook NS (1988) The pharmacology of potassium channels and their therapeutic potential. Trends Pharmacol Sci 9:21-28.

Cowan AI, Martin RL (1992) Ionic basis of membrane potential changes induced by anoxia in rat dorsal vagal motoneurones. J Physiol (Lond) 455:89-109.

Crunelli V, Erdemli G (1997) Pharmacological properties of the response of thalamocortical neurones to brief hypoxia. Soc Neurosci Abstr 23:2078.

Crunelli V, Lightowler S, Pollard CE (1989) A T-type $\mathrm{Ca}^{2+}$ current underlies low-threshold $\mathrm{Ca}^{2+}$ potentials in cells of the cat and rat lateral geniculate nucleus. J Physiol (Lond) 413:543-561.

Dubinsky JM, Rothman SM (1991) Intracellular calcium concentrations during "chemical hypoxia" and excitotoxic neuronal injury. J Neurosci 11:2545-2551.

Erdemli G, Crunelli V (1998) Hypoxia activates $I_{\mathrm{h}}$ in rat thalamocortical neurones in vitro. J Physiol (Lond) 506:150P.

Fujimoto K, Kita H (1993) Response characteristics of subthalamic neurons to the stimulation of the sensorimotor cortex in the rat brain. Brain Res 609:185-192.

Fujimura N, Tanaka E, Yamamoto S, Shigemori M, Higashi H (1997) Contribution of ATP-sensitive potassium channel to hypoxic hyperpolarization in rat hippocampal CA1 neurons in vitro. J Neurophysiol $77: 378-385$. 
Fujiwara N, Higashi H, Shimoji K, Yoshimura M (1987) Effects of hypoxia on rat hippocampal neurones in vitro. J Physiol (Lond) 384:131-151.

Gay LA, Stanfield PR (1977) $\mathrm{Cs}^{+}$causes a voltage-dependent block of inward K currents in resting skeletal muscle fibers. Nature 267:169-170.

Guyon A, Leresche N (1995) Modulation by different $\mathrm{GABA}_{\mathrm{B}}$ receptor types of voltage-activated calcium currents in rat thalamocortical neurones. J Physiol (Lond) 485:29-42.

Haddad GG, Donelly DF (1990) $\mathrm{O}_{2}$ deprivation induces a major depolarization in rain stem neurons in the adult but not in the neonatal rat. J Physiol (Lond) 429:411-428.

Haddad GG, Jiang C (1993) $\mathrm{O}_{2}$ deprivation in the central nervous system: on mechanisms and injury. Prog Neurobiol 40:277-318.

Hagiwara N, Irisawa H (1989) Modulation by intracellular $\mathrm{Ca}^{2+}$ of the hyperpolarization-activated inward current in rabbit single sino-atrial node cells. J Physiol (Lond) 409:121-141.

Hagiwara S, Miyazaki W, Mood W, Patlak J (1978) Blocking effects of barium and hydrogen ions on the potassium current during anomalous rectification in the starfish egg. J Physiol (Lond) 279:167-185.

Halliwell JV (1990) $\mathrm{K}^{+}$channels in the central nervous system. In: Potassium channels (Cook NS, ed), pp 348-381. Chichester, England: Wiley.

Hansen AJ (1985) Effect of anoxia on ion distribution in the brain. Pharmacol Rev 65:101-148.

Harris NC, Constanti A (1995) Mechanisms of block by ZD 7288 of the hyperpolarization-activated inward rectifying current in guinea pig substantia nigra neurons in vitro. J Neurophysiol 74:2366-2378.

Hochachka PW, Lutz PL, Sick T, Rosenthal M, van der Thillart G (1993) Surviving hypoxia. Boca Raton, FL: CRC.

Ingram L, Williams JT (1996) Modulation of the hyperpolarizationactivated current $\left(I_{\mathrm{H}}\right)$ by cyclic nucleotides in guinea-pig primary afferent neurons. J Physiol (Lond) 492:97-106.

Jones EG (1985) The thalamus. New York: Plenum.

Jones EG, Coulter JD, Burton H, Porter R (1977) Cells of origin and terminal distribution of cortical fibers arising in the sensory-motor cortex of monkeys. J Comp Neurol 173:53-80.

Kaplin AI, Snyder SH, Linden DJ (1996) Reduced nicotinamide adenine dinucleotide-selective stimulation of inositol 1,4,5-triphosphate receptors mediates hypoxic mobilization of calcium. J Neurosci 16:2001-2011.

Kass IS, Lipton P (1986) Calcium and long-term transmission damage following hypoxia in dentate gyrus and CA1 regions of the rat hippocampal slice. J Physiol (Lond) 378:313-334.

Kauppinen RA, McMahon HT, Nicholls DG (1988) $\mathrm{Ca}^{2+}$-dependent and $\mathrm{Ca}^{2+}$-independent glutamate release, energy status and cytosolic free $\mathrm{Ca}^{2+}$ concentration in isolated nerve terminals following metabolic inhibition: possible relevance to hypoglycemia and anoxia. Neuroscience 27:175-182.

Krnjevic K (1993) Membrane current activation and inactivation during hypoxia in hippocampal neurons. In: Surviving hypoxia (Hochachka PW, Lutz PL, Sick T, Rosenthal M, van der Thillart G, eds), pp 365-387. Boca Raton, FL: CRC.

Krnjevic K, Leblond L (1989) Changes in membrane currents of hippocampal neurons evoked by brief hypoxia. J Neurophysiol 62:15-30.

Leblond J, Krnjevic K (1989) Hypoxic changes in hippocampal neurones. J Neurophysiol 62:1-14.

Madl JE, Burgesser K (1993) Adenosine triphosphate depletion reverses sodium-dependent, neuronal uptake of glutamate in rat hippocampal slices. J Neurosci 13:4429-4444.

Martin LJ, Brambrink A, Koehler RC, Traystman RJ (1997) Primary sensory and forebrain motor systems in the new-born brain are preferentially damaged by hypoxia-ischemia. J Comp Neurol 377:262-285.

McCormick DA, Bal T (1997) Sleep and arousal: thalamocortical mechanisms. Annu Rev Neurosci 20:185-215.

McCormick DA, Pape HC (1990a) Properties of a hyperpolarizationactivated cation current and its role in rhythmic oscillation in thalamic relay neurones. J Physiol (Lond) 431:291-318.

McCormick DA, Pape HC (1990b) Noradrenergic and seratonergic modulation of a hyperpolarization-activated cation current in thalamic relay neurones. J Physiol (Lond) 431:319-342.

McCormick DA, Williamson A (1991) Modulation of neuronal firing mode in cat and guinea pig LGNd by histamine: possible cellular mechanisms of histaminergic control of arousal. J Neurosci 11:3188-3199.

Nicholls D, Attwell D (1990) The release and uptake of excitatory amino acids. Trends Pharmacol Sci 11:462-468.

Nolan PC, Waldrop TG (1996) Ventrolateral medullary neurons show age-dependent depolarization to hypoxia in-vitro. Dev Brain Res 91:111-120.

Pape H-C (1996) Queer current and pacemaker: the hyperpolarizationactivated cation current in neurons. Annu Rev Physiol 58:299-327.

Pape H-C, Mager R (1992) Nitric oxide controls oscillatory activity in thalamocortical neurons. Neuron 9:441-448.

Reid KH, Schurr A, Tseng MT, Edmonds HLJR (1984) Resistance to hypoxia in the rat hippocampal slice. Brain Res 302:387-391.

Salt TE, Meier CL, Seno N, Krucker T, Herrling PL (1995) Thalamocortical and corticocortical excitatory postsynaptic potentials mediated by excitatory amino acid receptors in the cat motor cortex in vivo. Neuroscience 64:433-442.

Sanchez-Prieto J, Sihra TS, Evans D, Ashton A, Dolly JO, Nicholls DG (1987) Botulinum toxin A blocks glutamate exocytosis from guinea-pig cerebral cortical synaptosomes. Eur J Biochem 165:675-681.

Soltesz I, Lightowler S, Leresche N, Jassik-Gerschenfeld D, Pollard CE, Crunelli V (1991) Two inward currents and the transformation of low-frequency oscillations of rat and cat thalamo-cortical cells. J Physiol (Lond) 441:175-197.

Stansfeld CE, Roper J, Ludwig J, Weseloh RM, Marsh SJ, Brown DA, Pongs O (1996) Elevation of intracellular calcium by muscarinic receptor activation induces a block of voltage-activated rat ether-à-go-go channel in a stable transfected cell line. Proc Natl Acad Sci USA 93:9910-9914.

Steinke W, Sacco RL, Mohr JP, Foulkes MA, Tatemichi TK, Wolf PA, Price TR, Hier DB (1992) Thalamic stroke, presentation and prognosis of infarcts and hemorrhages. Arch Neurol 49:703-710.

Steriade M, Llinas R (1988) The functional states of the thalamus and the associated neuronal interplay. Physiol Rev 68:649-742.

Steriade M, McCormick DA, Sejnowski TJ (1993) Thalamocortical oscillations in the sleeping and aroused brain. Science 262:679-685.

Szatkowski M, Attwell D (1994) Triggering and execution of neuronal death in brain ischemia: two types of glutamate release by different mechanisms. Trend Neurosci 17:359-365.

Szelies B, Herholz K, Pawlik G, Karbe H, Hebold I, Heiss WD (1991) Widespread functional effects of discrete thalamic infarction. Arch Neurol 48:178-182.

Turner JP, Anderson CM, Williams SR, Crunelli V (1997) Morphology and membrane properties of neurones in the cat ventrobasal thalamus in vitro. J Physiol (Lond) 505:707-726.

Watts AE, Williams JT, Henderson G (1996) Baclofen inhibition of the hyperpolarization-activated cation current, $I_{\mathrm{h}}$, in rat substantia nigra zona compacta neurons may be secondary to potassium current activation. J Neurophysiol 76:2262-2270.

Williams SR, Turner JP, Anderson CM, Crunelli V (1996) Electrophysiological and morphological properties of interneurones in the rat dorsal lateral geniculate nucleus in vitro. J Physiol (Lond) 490:129-147.

Williams SR, Turner JP, Hughes SW, Crunelli V (1997) On the nature of anomalous rectification in thalamocortical neurones of the cat ventrobasal thalamus in vitro. J Physiol (Lond) 505:727-747.

Yu SP, O'Malley MD, Adams PR (1994) Regulation of M current by intracellular calcium in bullfrog sympathetic ganglion neurones. J Neurosci 14:3487-3499.

Zhang J, Krnjevic K (1993) Whole-cell recording of anoxic effects on hippocampal neuron in slices. J Neurophysiol 69:118-127.

Zhang L, Pennefather P, Velumian A, Tymianski M, Harlton M, Carlen PL (1995) Potentiation of a slow $\mathrm{Ca}^{2+}$-dependent $\mathrm{K}^{+}$current by intracellular $\mathrm{Ca}^{2+}$ chelators in hippocampal CA1 neurones of rat brain slices. J Neurophysiol 74:2225-2241. 